\title{
Mafic Late Miocene-Quaternary volcanic rocks in the Kamchatka back arc region: implications for subduction geometry and slab history at the Pacific-Aleutian junction
}

\author{
Anna O. Volynets • Tatiana G. Churikova • \\ Gerhard Wörner • Boris N. Gordeychik • \\ Paul Layer
}

Received: 22 August 2008/ Accepted: 20 September 2009/Published online: 11 October 2009

(C) The Author(s) 2009. This article is published with open access at Springerlink.com

\begin{abstract}
New ${ }^{40} \mathrm{Ar} /{ }^{39} \mathrm{Ar}$ and published ${ }^{14} \mathrm{C}$ ages constrain voluminous mafic volcanism of the Kamchatka backarc to Miocene (3-6 Ma) and Late Pleistocene to Holocene $(<1 \mathrm{Ma})$ times. Trace elements and isotopic compositions show that older rocks derived from a depleted mantle through subduction fluid-flux melting $(>20 \%)$. Younger rocks form in a back arc by lower melting degrees involving enriched mantle components. The arc front and Central Kamchatka Depression are also underlain by plateau lavas and shield volcanoes of Late Pleistocene age. The focus of these voluminous eruptions thus migrated in time and may be the result of a high fluid flux in a setting where the Emperor seamount subducts and the slab steepens during rollback during terrain accretions. The northern termination of Holocene volcanism locates the
\end{abstract}

Communicated by M.W. Schmidt.

Electronic supplementary material The online version of this article (doi:10.1007/s00410-009-0447-9) contains supplementary material, which is available to authorized users.

A. O. Volynets $(\bowtie) \cdot$ T. G. Churikova · G. Wörner

GZG, Abteilung Geochemie, Universität Göttingen,

Goldschmidtstrasse 1, 37077 Gottingen, Germany

e-mail: a.volynets@gmail.com

\section{A. O. Volynets - T. G. Churikova}

Institute of Volcanology and Seismology, Piip Avenue 9,

Petropavlovsk-Kamchatsky, Russia

B. N. Gordeychik

LTD "MAKET", Brusov Lane 8/10, Building 1,

Moscow, Russia

e-mail: gordei@mail.ru

P. Layer

Department of Geology and Geophysics, University of Alaska

Fairbanks, 900 Yukon Drive, Fairbanks, USA edge of the subducting Pacific plate below Kamchatka, a "slab-edge-effect" is not observed in the back arc region.

Keywords Kamchatka $\cdot$ Back-arc $\cdot$ Plateau-basalts . Subduction · Trace elements · Isotopes

\section{Introduction}

The Kamchatka arc is a long-lived active subduction system with high magma production rates and unusually mafic magmas. It is situated in a complex plate boundary system with a triple junction between the Pacific-, Bering Sea- and Okhotsk Plates, transform boundaries, and active and extinct convergent boundaries. It is further complicated by subduction of the Emperor seamounts and a slab tear (Yogodzinski et al. 2001). Petrological and geochemical studies of Kamchatka volcanic rocks have focused on the evolution of single long-lived stratovolcanoes at the active arc front and their regional comparison (Duggen et al. 2007; Ponomareva et al. 2007; Portnyagin et al. 2005, 2007a, b; Churikova et al. 2001, 2007; Ozerov 2000; Volynets 1994; etc.). Numerous mafic monogenetic cones, lava fields, and plateau-basalts, found along the arc front, in the Central Kamchatka graben depression, and in the back arc region, however, are not well studied. Their age, spatial distribution, compositional variations, and magma sources are still poorly understood. These are large volumes of mafic magmas erupted during the Pliocene-Holocene, a time when Kamchatka evolved to its present complex setting, and thus these rocks may be crucial in better understanding the complex tectonic setting of the arc.

Quaternary volcanism in Central Kamchatka occurs in three zones parallel to the trench (Fig. 1): (1) Eastern Volcanic Front (EVF), (2) Central Kamchatka Depression 


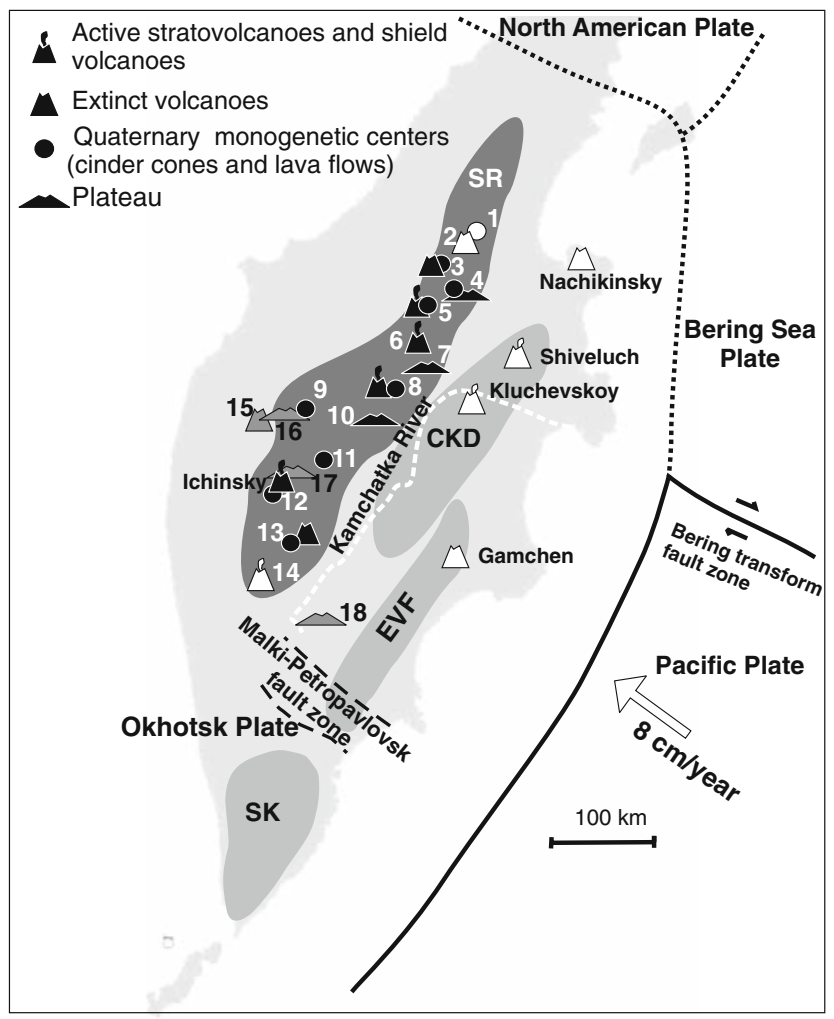

Fig. 1 General plate tectonic setting of Kamchatka and area studied. The outline of volcanic zones are from http://kamchatka.ginras.ru/ (Sredinny Range active volcanism zone after (Pevzner 2006)). Plate boundaries after DeMets et al. (1990), Zonenshain and Savostin (1979) and Lander et al. (1994). White arrow show the PacificOkhotsk convergence after Scholl (2007). SR Sredinny Range, CKD Central Kamchatka Depression, EVF Eastern Volcanic Front, SK South Kamchatka. Location of the sampled sites in Sredinny Range are numbered: 1 Tobeltsen cone, 2 Spokojny volcano, 3 Tekletunup stratovolcano and cinder cones, 4 Ozernovsky lava field, Left and Right Ozernaya plateau, 5 Sedanka lava field and Titila volcano, 6 Gorny Institute volcano, 7 Dvuh'urtochnoe plateau, 8 Alnej-Chashakondzha massif, 9 Kekuknajsky lava field, 10 Kruki Ridge, 11 Esso monogenetic cones, 12 Ichinsky stratovolcano and monogenetic lava field, 13 Achtang stratovolcano and monogenetic cones, 14 Khangar volcano. Location of samples from other studies, dated with ${ }^{40} \mathrm{Ar}-{ }^{39} \mathrm{Ar}$ method in this study: 15 Daik at Khukhch Mount (Perepelov et al. 2006b); 16 Shield volcano under Bolshoj (Perepelov et al. 2006a); 17 Shield volcano under Belogolovsky (Churikova et al. 2001); 18 Bakening plateau (Dorendorf et al. 2000a). Black symbols-volcanoes studied in this paper, gray symbols-samples from other studies, dated with ${ }^{40} \mathrm{Ar}-{ }^{39} \mathrm{Ar}$ method in this study; white symbols-volcanoes not studied in this paper

(CKD) as an intra-arc rift zone, and (3) the Sredinny Range (SR), the latter representing the back-arc of the presently active volcanic front in Kamchatka. The Southern Kamchatka arc, up to the latitude of the Malki-Petropavlovsk fault zone (Fig. 1), is considered as a continuation of Kurile island arc (Avdejko et al. 2002). The northern end of volcanic activity in Kamchatka is marked by Shiveluch volcano and has been related to the NW-SE Bering transform fault zone (e.g. Gorelchik et al. 1996;
Yogodzinski et al. 2001; Davaille and Lees 2004; Portnyagin et al. 2005), which marks the termination of the actively subducting Pacific plate.

Variable magma sources, their spatial variations, and the composition of different slab fluids involved in magma genesis were characterized for a $220 \mathrm{~km}$-wide transect across the arc at the latitude of the Kluchevskaya Group of volcanoes in (Churikova et al. 2001, 2007). According to these studies, the process of magma generation in Kamchatka has been described as the interaction of four components: a variably depleted N-MORB mantle wedge, OIB-type enriched mantle, slab fluids as well as slab melts at the northern termination of volcanism at Shiveluch (Yogodzinski et al. 2001). Melting degrees range from 10 to $20 \%$ and the presence of an OIB-type enriched source is required for back-arc magmatism.

This study focuses on the Kamchatka back arc region of the Sredinny Range (SR), a region with abundant Quaternary mafic volcanism for which the plate tectonic setting is basically unknown (Volynets 1994; Tatsumi et al. 1995; Churikova et al. 2001, 2007; Perepelov 2004, 2005; Trubitsin et al. 1998; Avdejko et al. 2002; Fedorov and Shapiro 1998; Pletchov 2008, etc.). We will present new geochemical, isotopical, and geochronological data for these volcanic rocks and their possible variations in space and time based on a representative collection that covers this region. We also discuss causes and mechanisms of melting and present a model for the origin and setting of back arc volcanism in Kamchatka.

\section{Geological setting and sampling}

The Eastern Volcanic Front terminates in the north with a group of late Pleistocene cinder cones on the eastern slope of the Kumroch Range almost as far north as the mouth of the Kamchatka River (Fig. 1). The Central Kamchatka Depression terminates at the Shiveluch volcano, but a few smaller monogenetic vents exist up to Nachikinsky volcano $\sim 150 \mathrm{~km} \mathrm{NE}$ of Shiveluch (Ponomareva et al. 2007). Today, the Sredinny Range is located $400 \mathrm{~km}$ behind the present trench, but represented the active volcanic front in the Eocene and switched to the present back-arc position after the accretion of the Kronotsky terrain and the formation of the recent active volcanic front (see also Appendix 1 in Electronic Supplementary Material). Some authors estimate the age of this collision between 40 and $20 \mathrm{Ma}$ (e.g. Alexeiev et al. 2006), others date it from 7 to $2 \mathrm{Ma}$ (Lander and Shapiro 2007). An active Benioff zone below the SR is observed only up to the latitude of the Holocene Khangar volcano at nearly $350 \mathrm{~km}$ above the slab (Gorbatov et al. 1997). Thus, back arc seismicity is absent further north even 
though there is evidence for abundant recent volcanism in this area.

In contrast to the main southern part of Kamchatka, where the Pacific Plate subducts below the Okhotsk Plate with a rate of $\sim 8 \mathrm{~cm} / \mathrm{a}$ (Scholl 2007), the Bering part of the North American Plate (north of Shiveluch volcano) is likely to have been stable relative to Kamchatka since Miocene times (Trubitsin et al. 1998; Baranov et al. 1991; Park et al. 2001; Baranov et al. 1991; Avdejko et al. 2002; Davaille and Lees, 2004). Therefore, there is no active subduction and we should not expect young volcanism in this back arc region. However, voluminous Holocene volcanic activity in SR back arc was documented by tephrochronological and radiocarbon methods at Khangar (Bazanova and Pevzner 2001), Ichinsky (Pevzner et al. 2000; Pevzner et al. 2002), and Alnej and Gorny Institute volcanoes (Pevzner 2006). Spokojny volcano is located in the northernmost part of the SR and was also active $\sim 5400{ }^{14} \mathrm{C}$ years B.P. (Pevzner 2006). Moreover, voluminous Holocene monogenetic mafic volcanism is also observed throughout the northern part of the SR with erupted volumes similar to those behind the active arc (Pevzner and Volynets 2006). Large fields of Late Pleistocene-Holocene cinder cones with basaltic and basaltic andesite composition were also described in the Sedanka river area (Dirksen et al. 2004). Monogenetic lava flows Kireunskij and Left Belaja River of the volcanic massif Alnej-Chashakondzha formed $2600{ }^{14} \mathrm{C}$ years B.P. (Pevzner 2004); the Ozernovsky lava flow covers an area of about $100 \mathrm{~km}^{2}$ and erupted about $9000{ }^{14} \mathrm{C}$ years B.P. ago (Pevzner et al. 2002). The northernmost Holocene monogenetic center of all Kamchatka is the Tobeltsen cinder cone, located about $180 \mathrm{~km}$ to the north of Shiveluch volcano. Its eruption occurred about $3500{ }^{14} \mathrm{C}$ years B.P. (Pevzner 2006). It is therefore obvious that large volumes of Holocene mafic lavas erupted all along the Sredinny Range back arc.

To elucidate the origin and source(s) of volcanism in this area we studied a $>200 \mathrm{~km}$ profile of monogenetic centers, plateau lavas, and stratovolcanoes along the Sredinny Range from the southern Achtang lava field through Ichinsky, Esso, Kekuknajsky, Kruki Ridge, Alnej, Dvuh'urtochnoe plateau, to Sedanka area, Gorny Institute volcano, Ozernovsky lava field and Tekletunup volcano in the north (Fig. 1; Appendix 1 in ESM). Particular attention was paid to young volcanoes, whose Holocene age was established by radiocarbon and tephrochronological dating (Dirksen et al. 2004; Pevzner et al. 2002; Pevzner 2004). Some older (but mostly undated) Late Miocene-Pliocene plateau basalts of Ozernovsky area, Kruki Ridge, and Dvuh'urtochnoe plateau were also sampled for comparison. The detailed description of the localities is found in Appendix 1 (ESM).
Analytical techniques

Analytical work for this study has been done at the Geowissenschaftliches Zentrum at the Georg-August Universität, Göttingen (Abteilung Geochemie). Concentrations of major and minor elements ( $\mathrm{Si}, \mathrm{Ti}, \mathrm{Al}, \mathrm{Fe}, \mathrm{Mn}, \mathrm{Mg}, \mathrm{Ca}, \mathrm{Na}$, $\mathrm{K}, \mathrm{P})$ as well as selected trace elements ( $\mathrm{Nb}, \mathrm{Zr}, \mathrm{Y}, \mathrm{Sr}, \mathrm{Rb}$, $\mathrm{Ga}, \mathrm{Zn}, \mathrm{Cu}, \mathrm{Ni}, \mathrm{Co}, \mathrm{Cr}, \mathrm{V}, \mathrm{Ba}, \mathrm{Sc})$ were analyzed in 117 samples by X-ray fluorescence spectroscopy (XRF) using a Philips PW 1480 automated sequential spectrometer. For calibration of major and trace elements, about 100 reference materials were used, a wide variety of synthetic and international geochemical reference samples from the US Geological Survey, the International Working Group "Analytical standards of minerals, ores and rocks", the National Research Council of Canada, the Geological Survey of Japan, the South African Bureau of Standards, the National Institute of Standards and Technology, etc. The glass disks, used for both major and trace element determination, were prepared by mixing prefused lithium tetraborate, lithium metaborate, and $\mathrm{LiF}$ (4,200 mg) with the sample powder $(700 \mathrm{mg})$ in platinum-gold crucibles and fused for $15 \mathrm{~min}$ at $1,100^{\circ} \mathrm{C}$ after which the melt was poured into pre-heated, polished $32 \mathrm{~mm}$-diameter molds. Elements were analyzed using a $3-\mathrm{kW}$ rhodium target $\mathrm{X}$-ray tube for sample excitation. The detailed operating conditions and the specific details of analytical precision and accuracy are given in Hartmann (1994) and Hartmann and Wedepohl (1993). Analytical errors for major elements are better than $1 \%$ and for trace elements around $5 \%$.

Additional trace elements were analyzed on 72 samples by inductively coupled plasma mass spectrometry (ICPMS). Whole-rock powders ( $\sim 100 \mathrm{mg}$ ) were dissolved (as described in Yokoyama et al. 1999) in Teflon beakers with a $4 \mathrm{ml}$ mixture of $\mathrm{HF} / \mathrm{HNO}_{3}(1: 1)$ and evaporated, then taken up in $2 \mathrm{ml} \mathrm{HF} / \mathrm{HClO}_{4}(1: 1)$ and refluxed two times with decreasing amounts of $\mathrm{HClO}_{4}$ at temperatures up to $190^{\circ} \mathrm{C}$. After evaporation, $0.5 \mathrm{ml}$ of $6 \mathrm{~N} \mathrm{HCl}$ was added and evaporated. For the measurements, samples were redissolved in $\mathrm{HNO}_{3}$. Rock standards JA-2 and BHVO-1 were analyzed continuously together with samples from which we estimate an external error about 10-15\% and higher for Ta. Some samples (293/1, 820904-1, 820904-22, SR0411, SR0424, SR0426, SR0428, SR0412, ALN0401) were repeatedly dissolved with different digestion schemes, but problems with unrealistically low $\mathrm{Nb} / \mathrm{Ta}$ ratios either due to incomplete acid digestion or loss of HFSE to the container walls remained. For these samples, $\mathrm{Nb}, \mathrm{Ta}, \mathrm{Hf}$, and $\mathrm{Zr}$ concentrations were determined by laser ablation technique on the glass disks with 1:3 lithium tetraborate/sample proportions. With this method, all samples, as well as standard sample BB gave close to chondritic ratios for HFS elements. From this, we 
recalculated concentrations based on XRF $\mathrm{Zr}$ values and the $\mathrm{Zr} / \mathrm{Nb}, \mathrm{Zr} / \mathrm{Hf}$ and $\mathrm{Nb} / \mathrm{Ta}$ ratios from laser ablation data.

Isotope ratios for $\mathrm{Sr}, \mathrm{Nd}$, and $\mathrm{Pb}$ were measured with a Finnigan MAT 262 RPQ II + mass spectrometer at Göttingen. Whole-rock powders $(\sim 100 \mathrm{mg}$ for $\mathrm{Sr}$ and $\mathrm{Nd}$ and $\sim 150 \mathrm{mg}$ for $\mathrm{Pb}$ ) were dissolved in $\mathrm{HF} / \mathrm{HNO}_{3}$. The $\mathrm{Sr}$ and $\mathrm{Nd}$-isotope ratios were corrected for mass fractionation to ${ }^{86} \mathrm{Sr} /{ }^{88} \mathrm{Sr}=0.1194$ and ${ }^{146} \mathrm{Nd} /{ }^{144} \mathrm{Nd}=0.7219$ and normalized to values for NBS987 (0.710245), and La Jolla (0.511847), respectively. Measured values of these standards over the last 3 years in Göttingen University were $0.710239 \pm 0.000004$ for $\mathrm{Sr}$ and $0.511844 \pm 0.000003$ for $\mathrm{Nd}$. External errors $(2 \sigma)$ are estimated at $<0.0004 \%$ for $\mathrm{Sr}$ and Nd isotopes. Lead isotopes were corrected to NBS981 standard (Todt et al. 1984). Normalization of our data to recommended values was done using variable mass fractionation factors $(0.046 \% ; 0.177 \% ; 0.013 \%$, and $0.004 \%)$ for different measurement periods. This was preferred over using an average fractionation factor of $0.075 \% \mathrm{amu}$ because one set of five samples had to be normalized with a relatively high fractionation correction of $0.177 \%$ amu. Procedural blanks for $\mathrm{Sr}, \mathrm{Nd}$ and $\mathrm{Pb}$ (261, 135 and $91 \mathrm{pg}$, respectively) were insignificant.

${ }^{40} \mathrm{Ar} /{ }^{39} \mathrm{Ar}$ step heat analysis for 11 samples was performed in the geochronology laboratory at the University of Alaska Fairbanks (UAF) on 250-500 micron-sized whole rock chips. The monitor mineral MMhb-1 (Samson and Alexander 1987) with an age of 513.9 Ma (Lanphere and Dalrymple 2000) was used to monitor neutron flux (and calculate the irradiation parameter, J). The samples and standards were wrapped in aluminum foil and were loaded into aluminum cans of $2.5 \mathrm{~cm}$ diameter and $6 \mathrm{~cm}$ height. The samples were irradiated in the research reactor of McMaster University in Hamilton, ON, Canada for 20 megawatt-hours.

Upon their return from the reactor, the samples and monitors were loaded into $2 \mathrm{~mm}$ diameter holes in a copper tray that was then loaded in an ultra-high vacuum extraction line. The monitors were fused, and samples heated, using a 6-watt argon-ion laser following the technique described in York et al. (1981), Layer et al. (1987), and Layer (2000). Argon purification was achieved using a liquid nitrogen cold trap and a SAES $\mathrm{Zr}-\mathrm{Al}$ getter at $400^{\circ} \mathrm{C}$. The samples were analyzed in a VG-3600 mass spectrometer at the Geophysical Institute, University of Alaska Fairbanks. Argon isotope ratios were corrected for system blank and mass discrimination, as well as calcium, potassium and chlorine interference reactions following McDougall and Harrison (1999). System blanks generally were $2 \times 10^{-16} \mathrm{~mol}^{40} \mathrm{Ar}$ and $2 \times 10^{-18} \mathrm{~mol}^{36} \mathrm{Ar}$, which are 10-50 times smaller than fraction volumes. Mass discrimination was monitored by running both calibrated air shots and a zero-age glass sample. These measurements were made on a weekly to monthly basis to check for changes in mass discrimination.

Age spectra are shown in Fig. 2. A summary of all the ${ }^{40} \mathrm{Ar} /{ }^{39} \mathrm{Ar}$ results is given in Table 1 , with all ages quoted to the \pm 1 sigma level and calculated using the constants of Steiger and Jaeger (1977). Analytical details can be found in Appendix 2 (ESM). The integrated age is the age given by the total gas measured and is equivalent to a potassiumargon (K-Ar) age. The spectrum provides a plateau age if three or more consecutive gas fractions represent at least $50 \%$ of the total gas release and are within two standard deviations of each other (Mean Square Weighted Deviation less than $\sim 2.7$ ). For some samples, multiple runs were done and the average age reflects a weighted average of the plateau or weighted mean ages for the runs.

\section{Results and discussion}

The age of plateau and back arc volcanism in Kamchatka

Previously, most age information on pre-Holocene magmatic complexes of Kamchatka was derived from topographic comparison and palinological data from sedimentary deposits (Ponomareva et al. 2007). First ${ }^{40} \mathrm{Ar} /{ }^{39} \mathrm{Ar}$ dates for volcanic rocks from the Central Kamchatka Depression (Calkins 2004) show that the lava shield that forms the base to the Holocene Kluchevskaya group was generated $260-280 \mathrm{ka}$ ago. We dated by ${ }^{40} \mathrm{Ar} /{ }^{39} \mathrm{Ar}$ several Late Miocene-Pliocene rocks from the Sredinny Range including plateau lavas and shield volcanoes underlying the Late Pleistocene-Holocene edifices (Table 1). Age spectra with well-defined plateaus (Table 1) are shown in Fig. 2 and range from $\sim 6 \mathrm{Ma}$ down to $\sim 20 \mathrm{ka}$.

1. Plateau lavas in the Sredinny Range back arc of Kamchatka are Late Miocene (6 Ma) to Pliocene (3 Ma) in age. Given this age range and the volume and area estimated from exposed sections (Ponomareva et al. 2007), these plateau lavas have an average eruption rate of $10 \times 10^{6}$ tons/year, which is about twice the "normal" arc magma production rate but still considerably less that Late Pleistocene to Holocene eruption rates in the Central Kamchatka Depression (100-160 × $10^{6}$ tons/year; Ponomareva et al. 2007). These plateau lavas, which presently are in a back arc position with respect to the active volcanic front, all have a well-expressed arc geochemical signature (see next section).

2. At 3.66 to $3.78 \mathrm{Ma}$ different types of rocks - arc type plateau and intra-plate basalts as dikes (Perepelov et al. 
Fig. $2{ }^{40} \mathrm{Ar} /{ }^{39} \mathrm{Ar}$ age spectra and isochron diagrams for basaltic rocks from Kamchatka. Ages are reported at the 1-sigma level (see Table 1). Location units correspond to the sample sites numbers in Fig. 1
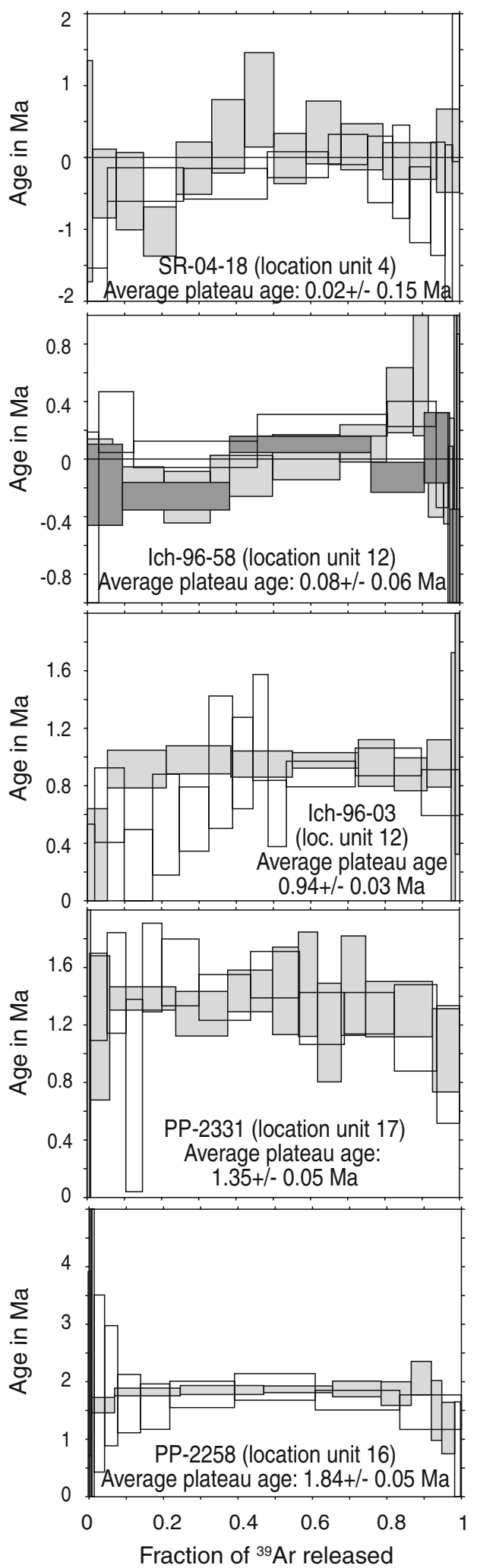
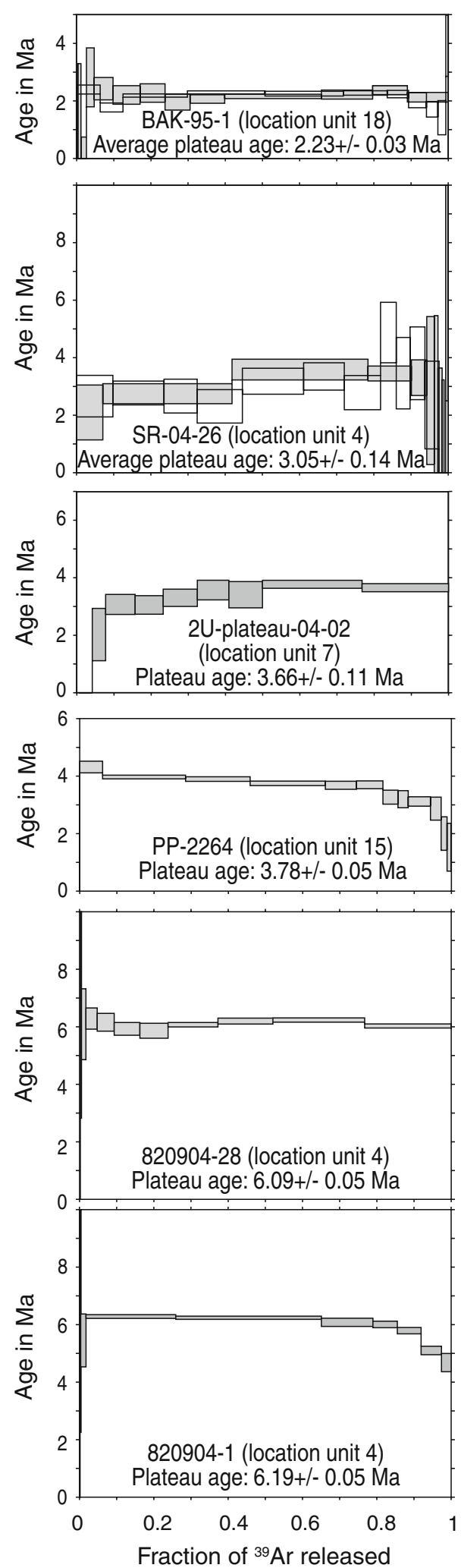

2006b)—erupted simultaneously suggesting the existence of different or transitional tectonic regimes at this time.
3. The younger rocks at the Sredinny Range $(<1$ Ma to recent) are less depleted in HFSE and combine the subduction and within-plate-type signatures (see 
Table 1 Summary of ${ }^{40} \mathrm{Ar} /{ }^{39} \mathrm{Ar}$ step heat analyses for Kamchatka samples

\begin{tabular}{|c|c|c|c|c|c|c|c|}
\hline \multirow[t]{2}{*}{ Unit (sample location \# from Fig. 1) } & \multirow[t]{2}{*}{ Sample } & \multirow{2}{*}{$\begin{array}{l}\text { Integrated } \\
\text { age (Ma) }\end{array}$} & \multirow{2}{*}{$\begin{array}{l}\text { Plateau } \\
\text { age }(\mathrm{Ma})\end{array}$} & \multicolumn{3}{|c|}{ Plateau information } & \multirow{2}{*}{$\begin{array}{l}\text { Average } \\
\text { age } \\
(\mathrm{Ma})\end{array}$} \\
\hline & & & & $\begin{array}{l}\text { Number of } \\
\text { fractions }\end{array}$ & $\begin{array}{l}{ }^{39} \mathrm{Ar} \\
\text { release } \\
(\%)\end{array}$ & MSWD & \\
\hline \multirow{2}{*}{$\begin{array}{l}\text { Right Ozernaya monogenetic cone } \\
(\# 4)\end{array}$} & \multirow[t]{2}{*}{ SR-04-18 } & $-0.03 \pm 0.13$ & $0.16 \pm 0.15$ & 8 & 76 & 0.4 & \multirow{2}{*}{$0.02 \pm 0.15$} \\
\hline & & $-0.37 \pm 0.12$ & $-0.15 \pm 0.16$ & 8 & 52 & 0.7 & \\
\hline \multirow{3}{*}{$\begin{array}{l}\text { Ichinsky volcano plateau, NE of } \\
\text { Gigigilen extrusion (\# 12) }\end{array}$} & \multirow[t]{3}{*}{ ICH-96-58 } & $-0.01 \pm 0.06$ & $-0.01 \pm 0.06$ & 8 & 59 & 1.9 & \multirow[t]{3}{*}{$0.08 \pm 0.06$} \\
\hline & & $-0.09 \pm 0.05$ & $0.04 \pm 0.05$ & 3 & 92 & 1.5 & \\
\hline & & $0.10 \pm 0.05$ & $0.18 \pm 0.05$ & 4 & 91 & 1.9 & \\
\hline \multirow{2}{*}{$\begin{array}{l}\text { Ichinsky volcano plateau, Oleny pass, } \\
\text { N of Ketachan Lake (\#12) }\end{array}$} & \multirow[t]{2}{*}{ ICH-96-03 } & $0.74 \pm 0.07$ & $0.90 \pm 0.07$ & 7 & 67 & 0.6 & \multirow[t]{2}{*}{$0.94 \pm 0.03$} \\
\hline & & $0.91 \pm 0.05$ & $0.95 \pm 0.04$ & 7 & 92 & 0.1 & \\
\hline \multirow{2}{*}{$\begin{array}{l}\text { Shield volcano under Belogolovsky } \\
\text { (\#17) }\end{array}$} & \multirow[t]{2}{*}{ PP-2331 } & $1.29 \pm 0.08$ & $1.33 \pm 0.08$ & 11 & 99 & 0.7 & \multirow{2}{*}{$1.35 \pm 0.05$} \\
\hline & & $1.32 \pm 0.07$ & $1.36 \pm 0.07$ & 8 & 87 & 0.2 & \\
\hline \multirow[t]{2}{*}{ Shield volcano under Bolshoj (\#16) } & \multirow[t]{2}{*}{ PP-2258 } & $1.61 \pm 0.14$ & $1.70 \pm 0.11$ & 6 & 92 & 0.3 & \multirow[t]{2}{*}{$1.84 \pm 0.05$} \\
\hline & & $1.80 \pm 0.04$ & $1.86 \pm 0.04$ & 6 & 85 & 0.2 & \\
\hline \multirow[t]{2}{*}{ Bakening plateau (\#18) } & \multirow[t]{2}{*}{ BAK-95-1 } & $2.13 \pm 0.07$ & $2.19 \pm 0.06$ & 9 & 95 & 0.5 & \multirow[t]{2}{*}{$2.23 \pm 0.03$} \\
\hline & & $2.20 \pm 0.04$ & $2.24 \pm 0.04$ & 6 & 82 & 0.6 & \\
\hline \multirow[t]{2}{*}{ Right Ozernaya plateau (\#4) } & \multirow[t]{2}{*}{ SR-04-26 } & $2.73 \pm 0.22$ & $2.97 \pm 0.20$ & 11 & 98 & 0.7 & \multirow[t]{2}{*}{$3.05 \pm 0.14$} \\
\hline & & $2.98 \pm 0.22$ & $3.13 \pm 0.21$ & 6 & 96 & 1.1 & \\
\hline Dvuhurtochnoe plateau (\#7) & 2-U-plateau-04-02 & $3.19 \pm 0.11$ & $3.66 \pm 0.11$ & 4 & 68 & 0.4 & $3.66 \pm 0.11$ \\
\hline Daik at Khukhch Mount (\#15) & PP-2264 & $3.69 \pm 0.04$ & $3.78 \pm 0.05$ & 4 & 53 & 1.1 & $3.78 \pm 0.05$ \\
\hline $\begin{array}{l}\text { Left Ozernaya plateau, } \\
\text { upper layer }(\# 2)\end{array}$ & $820904-28$ & $6.01 \pm 0.06$ & $6.09 \pm 0.05$ & 7 & 95 & 1.2 & $6.09 \pm 0.05$ \\
\hline $\begin{array}{l}\text { Left Ozernaya plateau, } \\
\text { lower layer (\#4) }\end{array}$ & 820904-1 & $6.05 \pm 0.04$ & $6.19 \pm 0.05$ & 5 & 85 & 1.6 & $6.19 \pm 0.05$ \\
\hline
\end{tabular}

For all samples, two runs were done, except for ICH-96-58 for which three runs were done. Ages quoted at $\pm 1 \sigma, M S W D$ Mean Square Weighted Deviates. Average age is weighted average of the plateau ages from each run

discussion below). These rocks are similar to present back arc rocks at Ichinsky (Churikova et al. 2001; Pearce 2005).

4. The formation of extensive plateau lavas and large shield volcanoes is a typical feature of arc volcanism in Kamchatka. These plateaus formed in different regions at different times: (a) Present back arc volcanic rocks $(<1 \mathrm{Ma})$ are underlain by the Sredinny Plateau lavas (6-3 Ma), (b) Late Pleistocene-Holocene volcanoes of the Central Kamchatka Depression are built on an extensive plateau of basalts and mafic andesites which range in age from 260 to $280 \mathrm{ka}$ and (c) the Eastern Volcanic Front also is constructed on extensive shield volcanoes which have not yet been dated but are likely of Late Pleistocene age.

Geochemistry of Kamchatka back arc lavas

The majority of studied rocks are olivine-clinopyroxeneplagioclase basalts with only a few more evolved compositions (andesites and dacites). In the former, olivine and plagioclase are always present as main phenocryst phases. Clinopyroxene is rare and often even completely absent as phenocrysts, with exception of Dvuh'urtochnoe plateau basalts, where it is very abundant. Rocks crystallized to a different degree, from almost aphyric to serial-porphyric, and are rich in $\mathrm{Fe}$ and $\mathrm{Ti}$ oxide phases (titanomagnetite and spinel) in the groundmass but rarely as phenocrysts.

Most Late Pleistocene-Holocene rocks belong to the calc-alkaline medium- $\mathrm{K}$ series and fall into the field of previously studied rocks of the Ichinsky volcano and surrounding monogenetic cones (Volynets et al. 1991; Churikova et al. 2001; Volynets and Churikova 2004; Volynets 2006; Bychkov et al. 2003). Some samples from Sedanka, Kekuknajsky and Tekletunup monogenetic fields belong to high-K series and fall into the field of monogenetic Ichinsky basalts with within-plate affinities.

The composition of the Late Miocene-Pliocene plateau basalts is different from any previously studied SR samples in major and trace elements (Figs. 3, 4, 5), and in 
Fig. $3 \mathrm{~K}_{2} \mathrm{O}$ vs. $\mathrm{SiO}_{2}, \mathrm{Na}_{2} \mathrm{O}$ vs. $\mathrm{SiO}_{2}, \mathrm{TiO}_{2}$ vs. $\mathrm{SiO}_{2}, \mathrm{Al}_{2} \mathrm{O}_{3}$ vs. $\mathrm{SiO}_{2}$ and $\mathrm{Al}_{2} \mathrm{O}_{3}$ vs. $\mathrm{MgO}$ diagrams for samples of the Sredinny Range. Light gray field corresponds to reference data from Ichinsky WPT (within-plate type basalts); dark gray field-SR IAB (island-arctype basalts) from Churikova et al. (2001). The overall trends are typical for Kamchatka arc volcanoes. Rocks from AlnejChashakondzha and Gorny Institute volcano have most evolved compositions; majority of other sampled sites are represented by basalts and basaltic andesites. Effect of plagioclase fractionation is negligible below $\mathrm{SiO}_{2} 55 \%$ and $\mathrm{MgO} 4 \%$. Classification lines on $\mathrm{K}_{2} \mathrm{O}$ (wt.\%) versus $\mathrm{SiO}_{2}$ (wt.\%) diagram after Le Maitre et al. (1989)
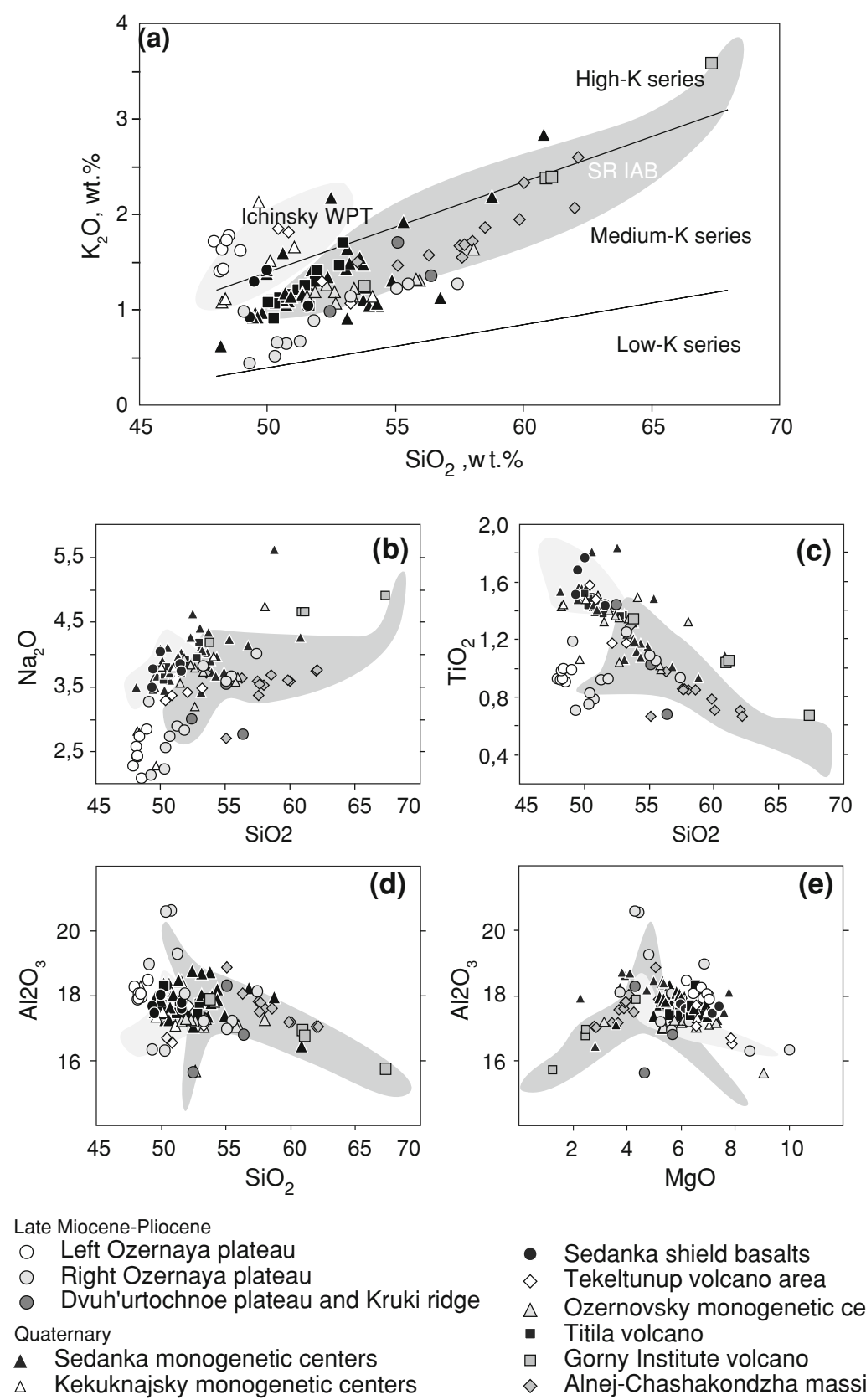

- Sedanka shield basalts

$\diamond \quad$ Tekeltunup volcano area

$\triangle$ Ozernovsky monogenetic centers

- Titila volcano

$\square \quad$ Gorny Institute volcano

$\diamond$ Alnej-Chashakondzha massif comparison with Late Pleistocene-Holocene rocks, show systematic enrichments in $\mathrm{CaO}$ and depletion in $\mathrm{TiO}_{2}$, $\mathrm{Na}_{2} \mathrm{O}$, and $\mathrm{P}_{2} \mathrm{O}_{5}$. While all plateau lavas have low $\mathrm{K}_{2} \mathrm{O}$ (Fig. 3a), samples from Left Ozernaya plateau belong to high-K series and have the highest $\mathrm{K}_{2} \mathrm{O}$ values (Fig. 3a). The Left Ozernaya plateau is also characterized by low silica and high $\mathrm{FeO}$ and $\mathrm{MnO}$ concentrations and by high $\mathrm{TiO}_{2}$ and $\mathrm{P}_{2} \mathrm{O}_{5}$ compared to other analyzed plateau basalts. It is interesting that the Right- and Left-Ozernaya plateaus (ROP and LOP) have rather different major element compositions, although geographically they are located very close to each other.

All trace elements patterns have typical arc signatures with variably depleted HFSE and HREE and are enriched in LILE and LREE (Fig. 4). Most (with the exception of single analysis of Kruki Ridge basalt) have HREE concentration lower than NMORB expressed as $\mathrm{Yb}_{\mathrm{NMORB}} /$ $\mathrm{Yb}_{\text {sample }}$ by a factor of 1.05-2.5. LOP, ROP and some Holocene and Late Pleistocene basalts of Alnej-Chashakondzha massif and Tekletunup area show a maximum 
degree of depletion $\left(\mathrm{Yb}_{\mathrm{NMORB}} / \mathrm{Yb}_{\text {sample }}>1.65\right)$, i.e. this factor is not correlated with the age of the studied rocks.

Most Late Pleistocene-Holocene lavas have $\mathrm{Nb}$ and $\mathrm{Ta}$ concentrations (compared to LREE) higher than in typical arc-front lavas in Kamchatka, reflecting variable enrichment of the source in these elements (Group 1; Fig. 4a-e) compatible with previously published analyses for the SR (Churikova et al. 2001). They form a rather coherent group in all trace element ratio diagrams and have relatively low (but still arc-like) fluid mobile/HFSE elements ratios $(\mathrm{Ba} /$ $\mathrm{Nb}, \mathrm{Th} / \mathrm{Ta}, \mathrm{U} / \mathrm{Nb}$ ).

Rocks from the Alnej-Chashakondzha volcanic massif (Group 2) have an intermediate composition between Late Pleistocene-Holocene and Late Miocene-Pliocene plateaus (Fig. 5a, b, e). These rocks have trace element patterns similar to lavas from Achtang volcano in southern part of SR.

Older rocks from the underlying Late MiocenePliocene plateau basalts (Group 3; $3.05 \pm 0.14 \mathrm{Ma}-$ $6.19 \pm 0.05 \mathrm{Ma}$, Table 1) show arc-type trace element patterns similar to the rocks of the Eastern Volcanic Front, some are even more depleted in HREE. Group 3 includes basalts from the Right Ozernaya plateau, Dvuh'urtochnoe plateau basalts, and Kruki Ridge basalts, as well as a single analysis of a Pleistocene cinder cone from the Kekuknajsky area. All these older plateau rocks are much more depleted in HFSE and REE compared to younger SR rocks, while fluid-mobile elements (e.g. Ba, $\mathrm{Pb}, \mathrm{Sr}$ ) have similar or higher concentrations. This group is thus enriched in $\mathrm{U} / \mathrm{Nb}, \mathrm{Ba} / \mathrm{Nb}, \mathrm{Th} / \mathrm{Ta}, \mathrm{Sb} / \mathrm{Ce}$, and $\mathrm{La} /$
Fig. 4 N-MORB-normalized trace elements patterns for rocks from Sredinny Range. Gray reference field includes the entire data set for SR Late Pleistocene-Holocene lavas, presented in this paper. The order of incompatible elements is after Hofmann (1988) with Cs and all REE added. N-MORB and OIB values after Sun and McDonough (1989). OIB composition: black dots. The arc signature is well pronounced even on the very northern part of the SR (a, c, e, g), where there is no subducting plate expected in Quaternary times. Late Pleistocene-Holocene volcanic rocks $(\mathbf{a}-\mathbf{e}, \mathbf{g})$ are less enriched in LILE and less depleted in HFSE-compared to older plateau lavas (f, h)

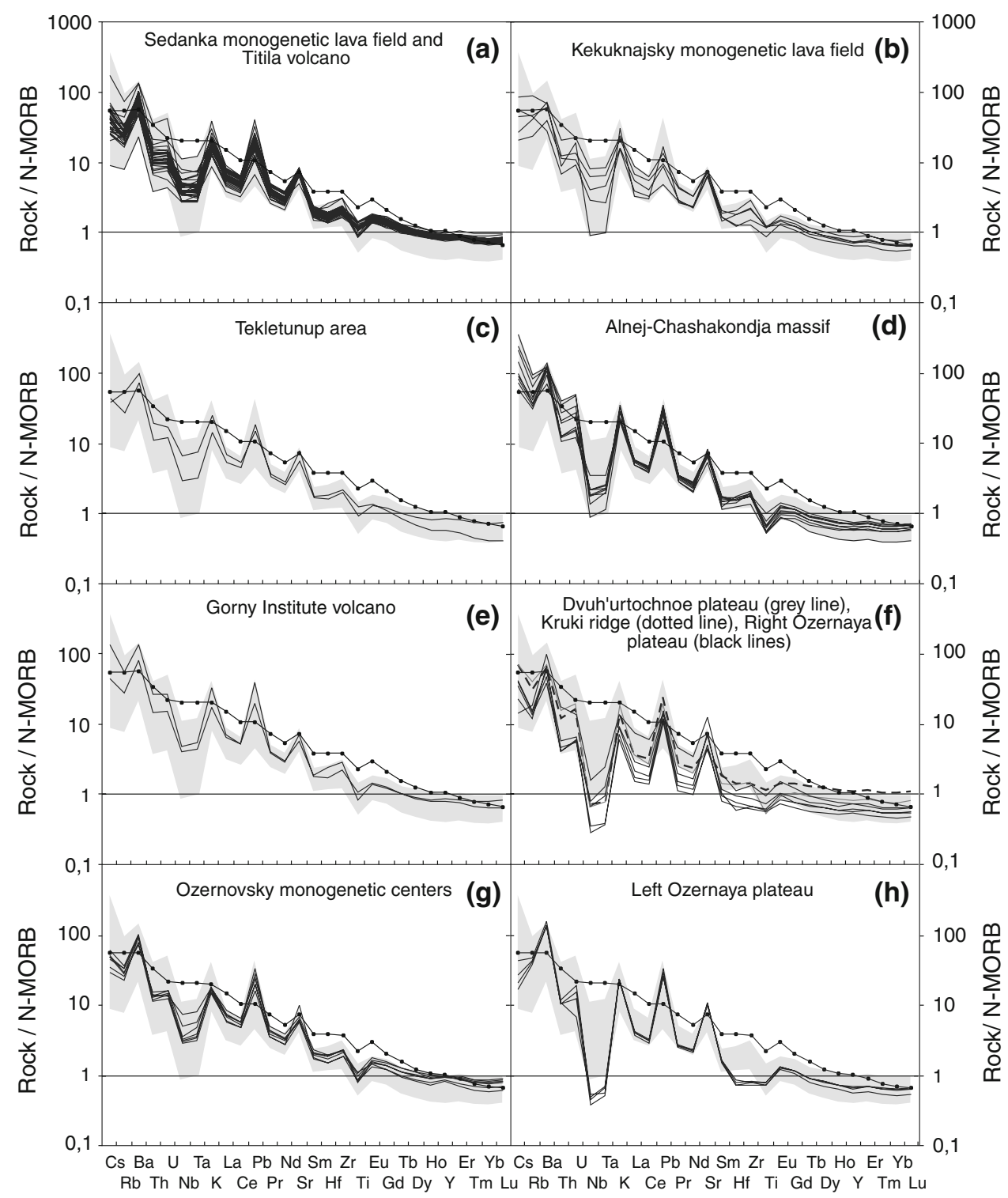


Fig. 5 Incompatible element ratio plots for SR rocks. Symbols are same as in Fig 3. a $\mathrm{Th} / \mathrm{Yb}$ versus $\mathrm{Ta} / \mathrm{Yb}$ (Pearce 1983) distinguishes between primitive island arc rocks from depleted and enriched mantle sources. The displacement from the mantle field to higher $\mathrm{Th} / \mathrm{Yb}$ ratios is caused by slab fluid/ melt enrichment in Th over $\mathrm{Yb}$, whereas variations in the mantle source are shown by a change in both ratios. Groups 3 and 4 rocks have a depleted mantle source even compared to NMORB; Group 1 has a variable addition of an enriched mantle source component. Group 2 takes the intermediate position. $\mathbf{b}, \mathbf{d}, \mathbf{e}, \mathbf{f}$ low fluidmobile/immobile element ratios are typical for Group 1; highest values are observed in Group 4. Rocks from Group 2 (AlnejChashakondzha) are similar in $\mathrm{U} / \mathrm{Nb}$ (f) to Group 3 and 4 (plateau basalts), but in $\mathrm{Nb} / \mathrm{Ta}$, $\mathrm{Zr} / \mathrm{Sm}$ and $\mathrm{Zr} / \mathrm{Y}$ (c, d) to Quaternary monogenetic basalts
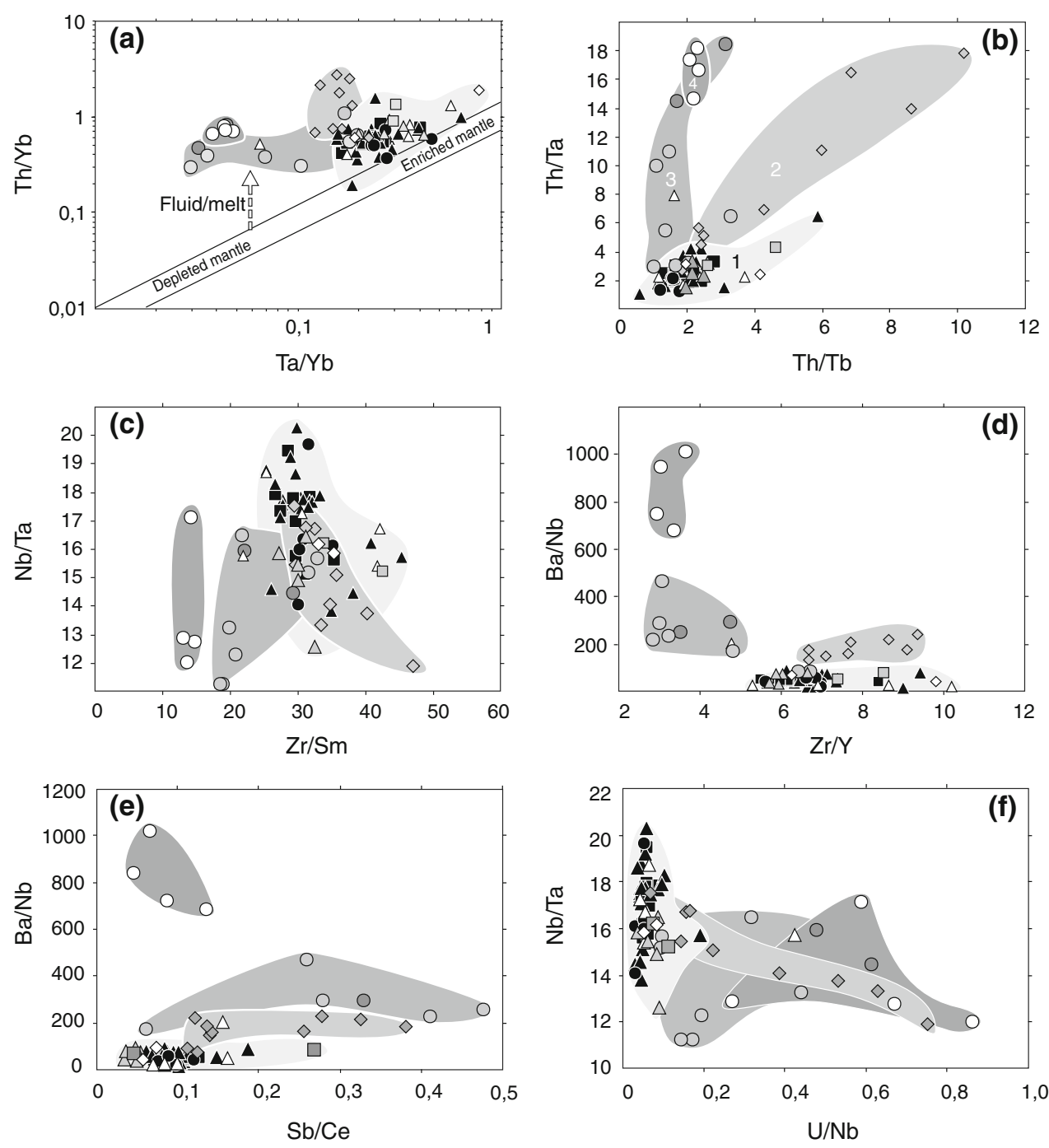

Group 1: Sedanka, Right Ozernaya monogenetic, Gorny Institute, Kekuknajsky (except sample 415/1)

Group 2: Alnej-Chashakondzha

Group 3: Right Ozernaya plateau, Dvuh'urtochnoe plateau, Kruki Ridge, 415/1 (Kekuknajsky area)

Group 4: Left Ozernaya plateau
$\mathrm{Yb}$ compared to the younger Late Pleistocene-Holocene monogenetic basalts (Fig. 5).

An extreme case in all diagrams is represented by Left Ozernaya plateau basalts (Group 4), the oldest studied samples $(6.19 \pm 0.05$ to $6.09 \pm 0.05 \mathrm{Ma})$. These are distinguishable from other plateau lavas in many trace element ratios (Fig. 5), but are particularly enriched in $\mathrm{Ba}, \mathrm{Sr}$, and LREE, depleted in HFSE, and they have higher $\mathrm{La} / \mathrm{Yb}$, $\mathrm{Th} / \mathrm{Ta}, \mathrm{Th} / \mathrm{Yb}$ and lower $\mathrm{Zr} / \mathrm{Y}, \mathrm{Zr} / \mathrm{Sm}$ ratios (Fig. 5; Table 2). These rocks have the highest $\mathrm{Ba} / \mathrm{Nb}$ ratio observed (Fig. 5d) -5 times higher than in other plateau lavas and up to 80 times higher than in any other samples from the area. These large variations in $\mathrm{Ba} / \mathrm{Nb}$ ratio are due to both variable $\mathrm{Nb}$ and $\mathrm{Ba}$ contents, although influence of low $\mathrm{Nb}$ concentrations to this ratio is more pronounced.

Portnyagin et al. (2005) report substantial variations in composition of volcanic rocks from the Central Kamchatka Depression with respect to the location of volcanoes relative to the Bering zone of transform faults: $\mathrm{Nb} / \mathrm{Y}, \mathrm{Dy} / \mathrm{Yb}$ are higher and $\mathrm{Ba} / \mathrm{Nb}$ is lower in northern CKD volcanic rocks (volcanoes Khajlula and Nachikinsky, north of the Bering transform fault) in comparison with Kluchevskoy and Shiveluch, located above the actively subducting Pacific Plate, south of the Bering 


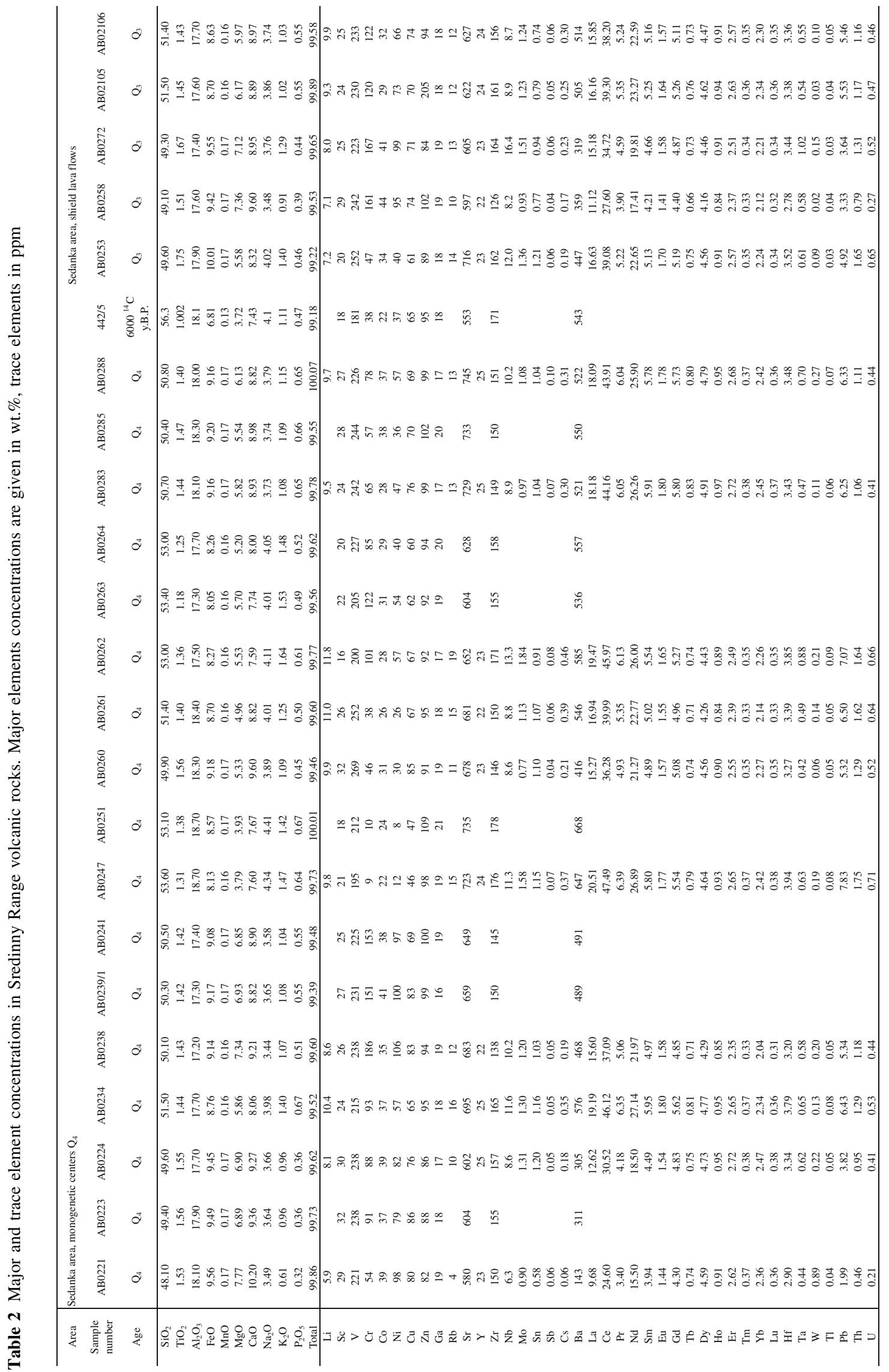




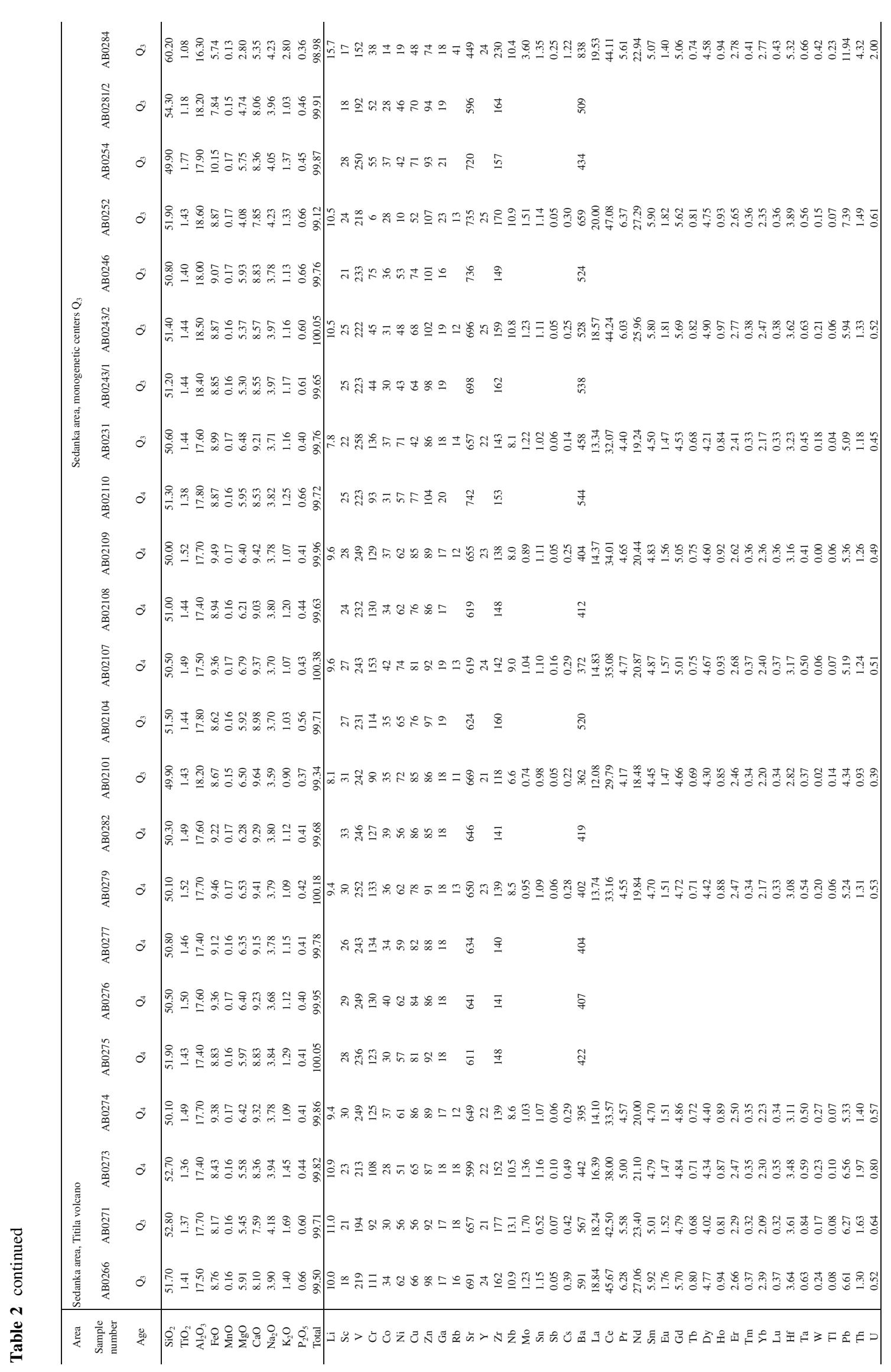




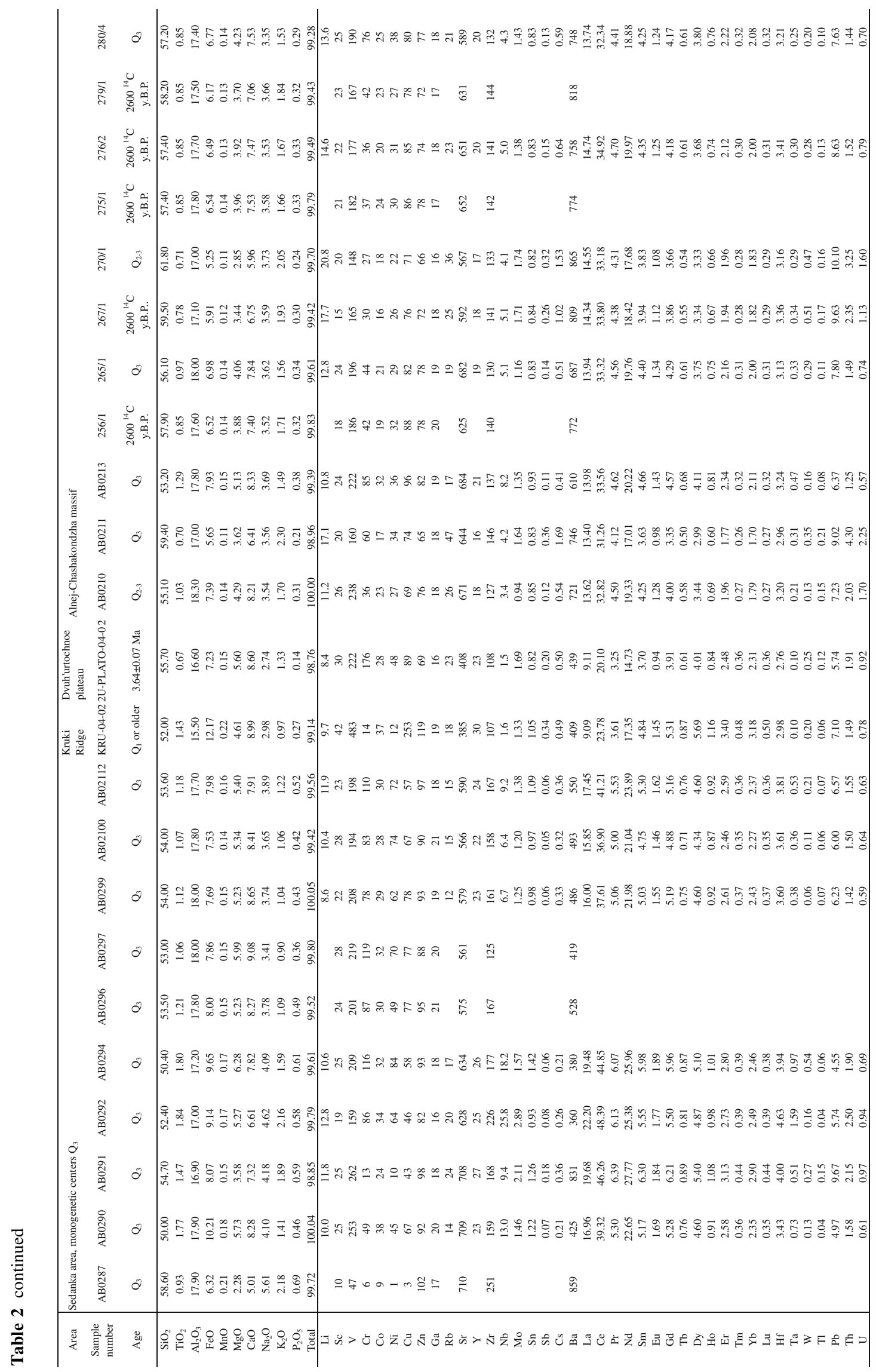




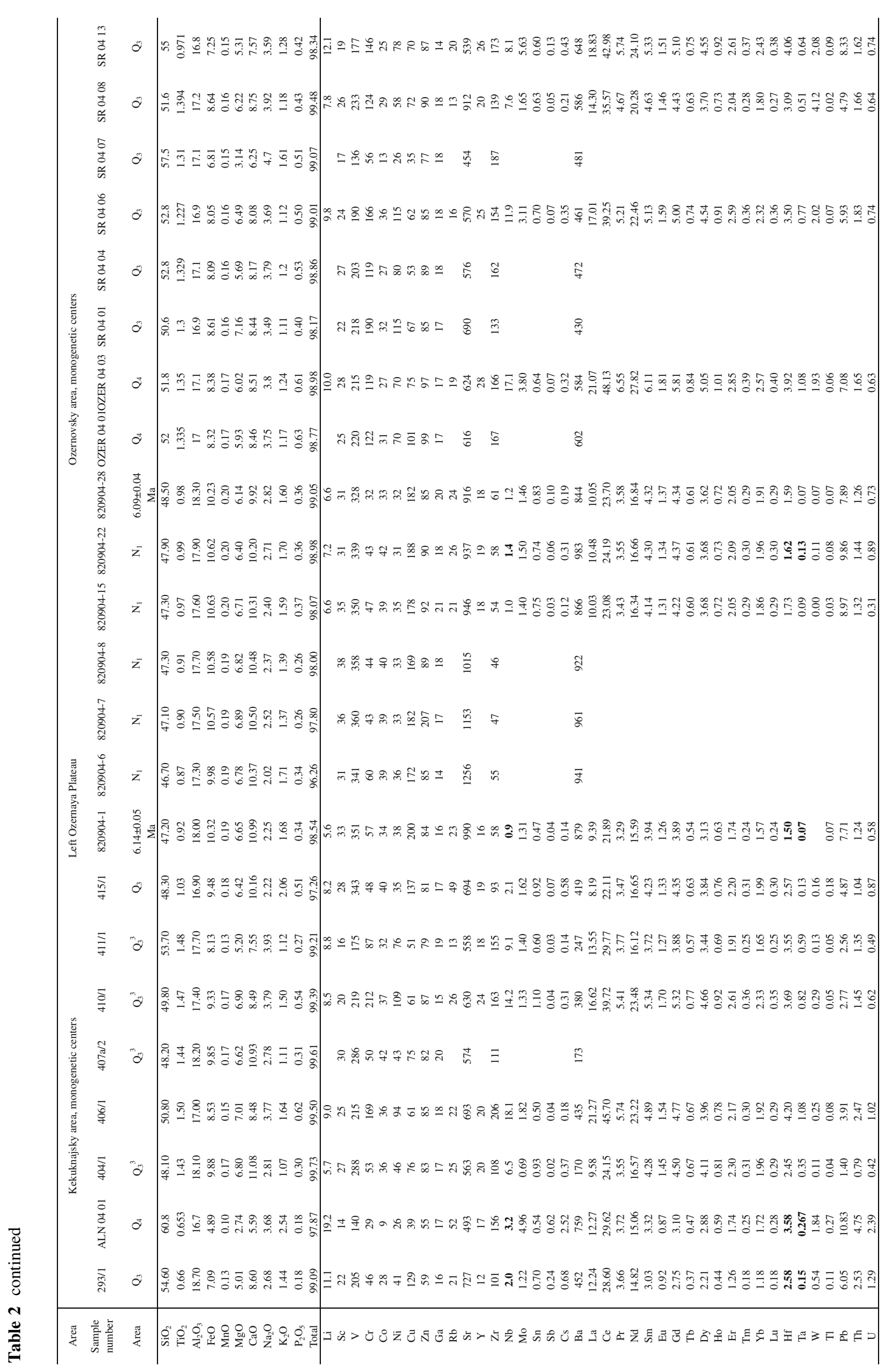




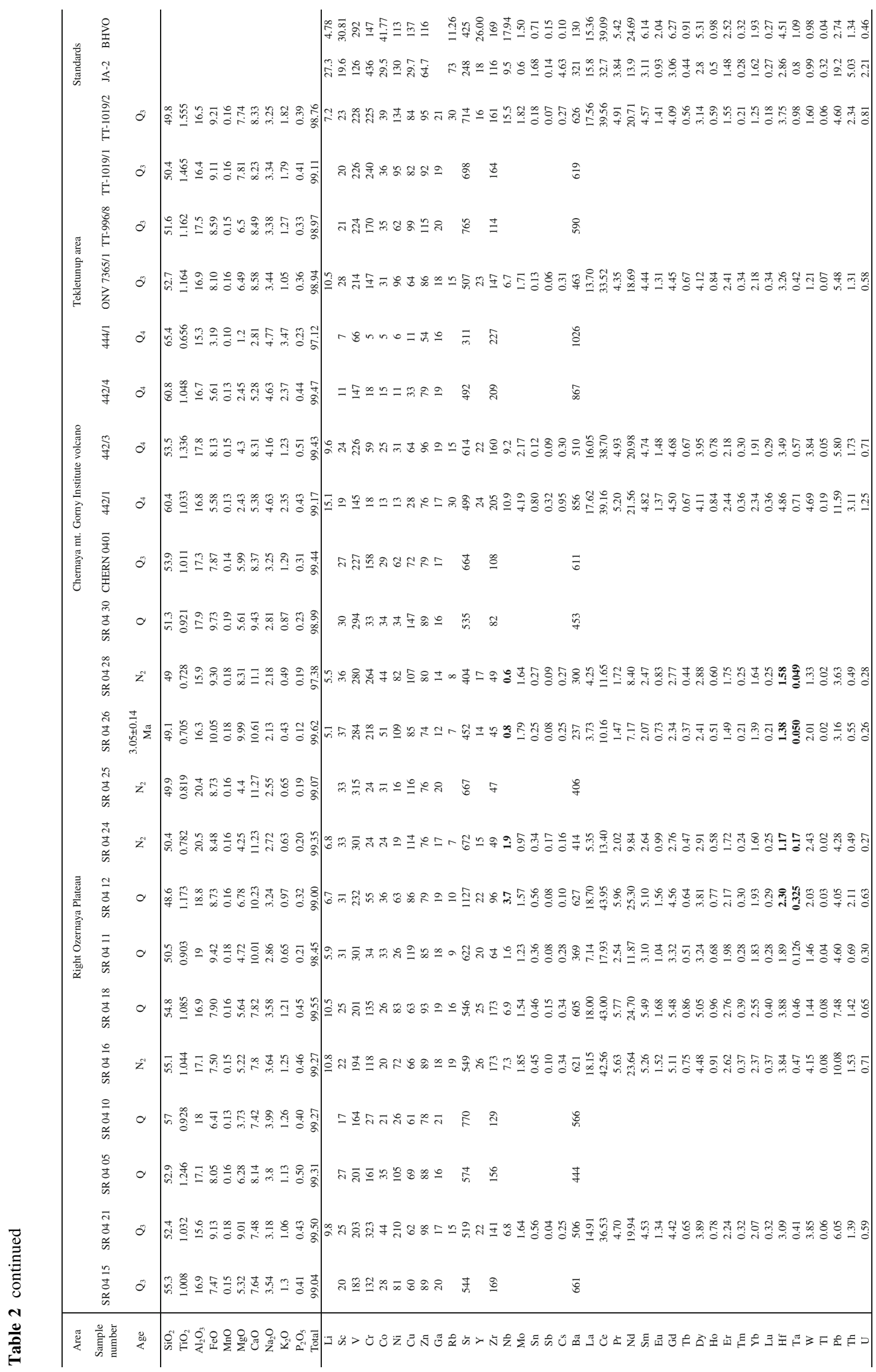


Fig. 6 a $\mathrm{Nb} / \mathrm{Y}, \mathrm{Ba} / \mathrm{Nb}$ and $\mathrm{Dy} /$ $\mathrm{Yb}$ variations in SR back arc rocks from the south to the north. b Northern CKD rocks (after Portnyagin et al. 2005) for reference.An increase in $\mathrm{Nb} / \mathrm{Y}$, $\mathrm{Dy} / \mathrm{Yb}$ and the $\mathrm{Dy} / \mathrm{Yb}$ decrease in CKD rocks at crossing the Bering transform fault marks the edge of the actively subducting Pacific plate. Note that in Sredinny Range back arc rocks the observed

compositional variations are not connected with the location of volcanic centers relative to the Pacific plate edge (Bering transform fault). At the same time, SR Late Miocene-

Pliocene volcanic rocks (plateau) differ from Late Pleistocene-Holocene volcanic rocks (stratovolcanoes and monogenetic centers) by lower $\mathrm{Nb} / \mathrm{Y}, \mathrm{Dy} / \mathrm{Yb}$ and higher $\mathrm{Ba} / \mathrm{Nb}$ ratios
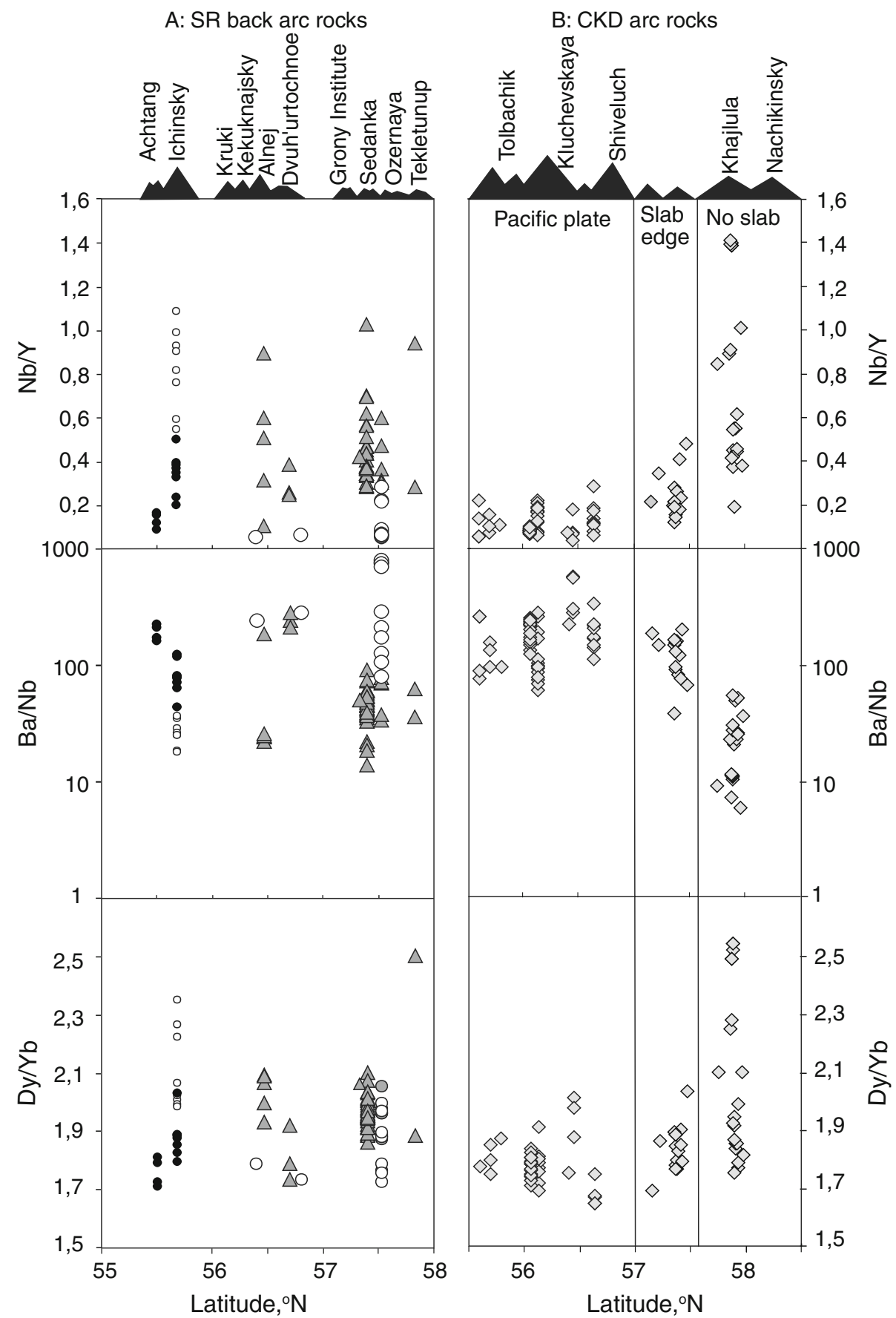

- Late Miocene-Pliocene plateau basałts CKD rocks after (Portnyagin et al., 2005)

$\triangle$ Late Pleistocene-Holocene volcanic rocks

- Ichinsky WPT (Churikova et al., 2001)

- SR IAB (Churikova et al., 2001) transform fault. In contrast, according to our data, volcanic rocks from Sredinny Range do not show any regular spatial changes in composition but rather vary with time (Fig. 6).
$\mathrm{Sr}, \mathrm{Nd}$, and $\mathrm{Pb}$ isotopes

Sr-, Nd-, and Pb-isotope data are presented in Table 3. All analyzed samples have "primitive" $\mathrm{Sr}$ and $\mathrm{Nd}$ 
Table 3 Isotopic composition of ${ }^{87} \mathrm{Sr} /{ }^{86} \mathrm{Sr},{ }^{143} \mathrm{Nd} /{ }^{144} \mathrm{Nd},{ }^{206} \mathrm{~Pb} /{ }^{204} \mathrm{~Pb},{ }^{207} \mathrm{~Pb} /{ }^{204} \mathrm{~Pb}$ and ${ }^{208} \mathrm{~Pb} /{ }^{204} \mathrm{~Pb}$ in the representative analysis of $\mathrm{Sredinny}$ Range volcanic rocks

\begin{tabular}{|c|c|c|c|c|c|c|c|c|c|c|}
\hline Sample number & ${ }^{87} \mathrm{Sr} /{ }^{86} \mathrm{Sr}$ & 2SE & ${ }^{143} \mathrm{Nd} /{ }^{144} \mathrm{Nd}$ & 2SE & ${ }^{206} \mathrm{~Pb} /{ }^{204} \mathrm{~Pb}$ & 2SE & ${ }^{207} \mathrm{~Pb} /{ }^{204} \mathrm{~Pb}$ & 2SE & ${ }^{208} \mathrm{~Pb} /{ }^{204} \mathrm{~Pb}$ & 2SE \\
\hline $\mathrm{AB} 0221$ & 0.702800 & 0.000013 & 0.513108 & 0.000006 & 18.140 & 0.002 & 15.450 & 0.002 & 37.777 & 0.005 \\
\hline AB0262 & 0.703247 & 0.000014 & 0.513082 & 0.000013 & 18.195 & 0.004 & 15.442 & 0.004 & 37.797 & 0.009 \\
\hline AB0292 & 0.703240 & 0.000017 & 0.513026 & 0.000006 & 18.166 & 0.002 & 15.486 & 0.002 & 37.915 & 0.005 \\
\hline AB02100 & 0.703227 & 0.000012 & 0.513061 & 0.000009 & 18.230 & 0.002 & 15.458 & 0.002 & 37.859 & 0.004 \\
\hline $\mathrm{AB} 0213$ & 0.703249 & 0.000014 & 0.513060 & 0.000006 & 18.235 & 0.003 & 15.485 & 0.002 & 37.928 & 0.007 \\
\hline $267 / 1$ & 0.703320 & 0.000012 & 0.513047 & 0.000005 & 18.233 & 0.012 & 15.459 & 0.010 & 37.863 & 0.025 \\
\hline $293 / 1$ & 0.703074 & 0.000012 & 0.513073 & 0.000006 & 18.217 & 0.002 & 15.447 & 0.002 & 37.794 & 0.005 \\
\hline 2U-PLATO-04-02 & 0.703119 & 0.000014 & 0.513089 & 0.000005 & 18.202 & 0.001 & 15.469 & 0.001 & 37.853 & 0.003 \\
\hline $406 / 1$ & 0.703106 & 0.000011 & 0.513036 & 0.000006 & 18.112 & 0.008 & 15.417 & 0.007 & 37.676 & 0.017 \\
\hline $410 / 1$ & 0.703219 & 0.000012 & 0.513018 & 0.000006 & 18.100 & 0.002 & 15.447 & 0.002 & 37.808 & 0.005 \\
\hline $415 / 1$ & 0.703352 & 0.000016 & 0.513107 & 0.000007 & 18.208 & 0.002 & 15.452 & 0.002 & 37.724 & 0.004 \\
\hline 820904-28 & 0.703359 & 0.000014 & 0.513084 & 0.000007 & 18.261 & 0.003 & 15.441 & 0.002 & 37.759 & 0.005 \\
\hline SR 0421 & 0.703242 & 0.000015 & 0.513050 & 0.000006 & 18.231 & 0.002 & 15.456 & 0.002 & 37.840 & 0.004 \\
\hline OZER 0403 & 0.703199 & 0.000013 & 0.513044 & 0.000006 & 18.227 & 0.003 & 15.476 & 0.003 & 37.892 & 0.006 \\
\hline SR 0426 & 0.703307 & 0.000011 & 0.513065 & 0.000006 & 18.237 & 0.002 & 15.450 & 0.002 & 37.828 & 0.005 \\
\hline SR 0418 & 0.703267 & 0.000014 & 0.513044 & 0.000005 & 18.223 & 0.003 & 15.455 & 0.003 & 37.838 & 0.007 \\
\hline SR 0411 & 0.703305 & 0.000012 & 0.513049 & 0.000005 & 18.211 & 0.003 & 15.448 & 0.003 & 37.817 & 0.006 \\
\hline $442 / 3$ & 0.703237 & 0.000012 & 0.513058 & 0.000007 & 18.225 & 0.002 & 15.461 & 0.002 & 37.856 & 0.007 \\
\hline TT-1019/1 & 0.703557 & 0.000012 & 0.512916 & 0.000006 & 18.125 & 0.002 & 15.446 & 0.002 & 37.833 & 0.005 \\
\hline
\end{tabular}

isotopic compositions, as is typical for Kamchatka rocks from the EVF and CKD (Fig. 7) and fall in the range of ${ }^{87} \mathrm{Sr} /{ }^{86} \mathrm{Sr} 0.703074$ to 0.703359 and ${ }^{143} \mathrm{Nd} /{ }^{144} \mathrm{Nd} 0.513018$ to 0.513106. The exceptions are samples AB0221 (Holocene cinder cone from Sedanka area), which has a very low, N-MORB-like $\mathrm{Sr}$ isotope ratio and also a slightly higher Nd isotope ratio (0.513108), and TT-1019/ 1 (Pleistocene cinder cone from Tekletunup area), which shows relatively high $\mathrm{Sr}(0.703557)$ and low $\mathrm{Nd}$ (0.512916) isotope ratios, close to the enriched source of Churikova et al. (2001). Lead isotopes are within the field of previously reported SR compositions (Fig. 8). Minor variations in lead isotopes exist but are relatively insignificant with respect to the overall variations in Kamchatka (see inset in Fig. 8a). A noteworthy feature is the complete absence of correlations between radiogenic isotopes and fluid-mobile/immobile element ratios (Fig. 8d). Another surprising result is the isotopic similarity for most samples, despite large geographical, geological, and compositional differences given by variable HFSE/HREE ratios and HFSE contents, which indicate a heterogeneous mantle source. Within the small isotopic compositional range, there is no systematic spatial variation. However, with respect to age, minor isotopic differences occur, which we will exploit in the reconstruction of magma sources with respect to their tectonic setting.

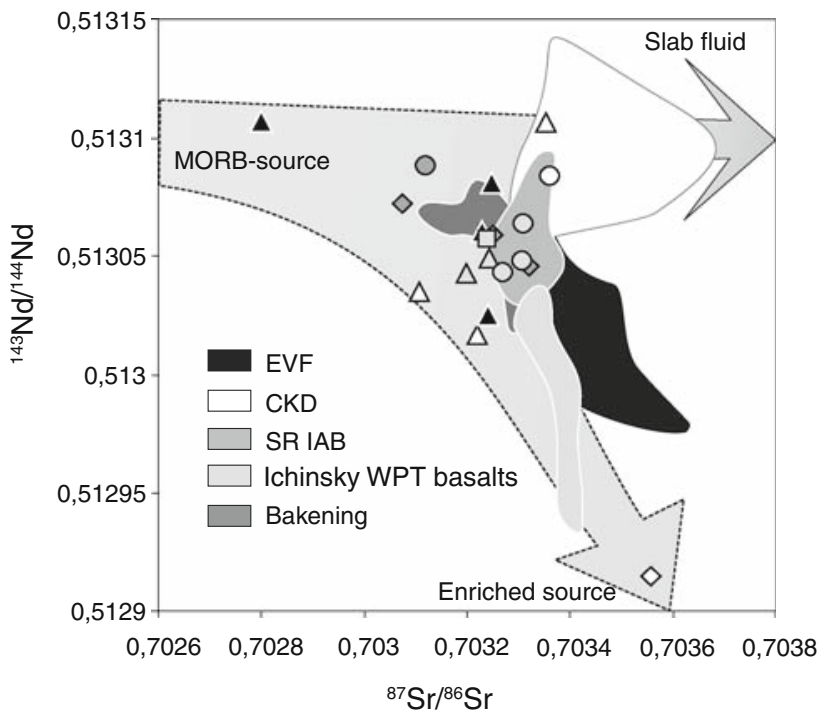

Fig. $7{ }^{143} \mathrm{Nd} /{ }^{144} \mathrm{Nd}$ vs. ${ }^{87} \mathrm{Sr} /{ }^{86} \mathrm{Sr}$ fields show previously reported compositions for Kamchatka rocks (Churikova et al. 2001; Dorendorf et al. 2000a, b) and new data from the SR back arc. Arrows indicate three components: slab fluid, MORB-type source and enriched mantle source. Other symbols like in Fig. 3

\section{Interpretation}

The rocks sampled along the SR, are divided into two main types of different age: groups 1 and 2: overlying Late 
Fig. 8 a, b $\mathrm{Pb}$ isotope systematic in comparison with previously studied Kamchatka (Churikova et al. 2001;

Dorendorf et al. 2000a, b), Aleutians rocks (Miller et al. 1994), N-MORB (Miller et al. 1994) and pelagic Pacific sediments (Miller et al. 1994; Kersting and Arculus 1995). c, d ${ }^{208} \mathrm{~Pb} /{ }^{204} \mathrm{~Pb}$ vs. ${ }^{87} \mathrm{Sr} /{ }^{86} \mathrm{Sr}$ and

${ }^{87} \mathrm{Sr} /{ }^{86} \mathrm{Sr}$ vs. $\mathrm{Ce} / \mathrm{Pb}$ for $\mathrm{SR}$ rocks in comparison with previously reported Kamchatka and Aleutians rocks (Miller et al. 1994). Aleutian samples are marked with crosses, other symbols as in Fig. 3, fields as in Fig. 7
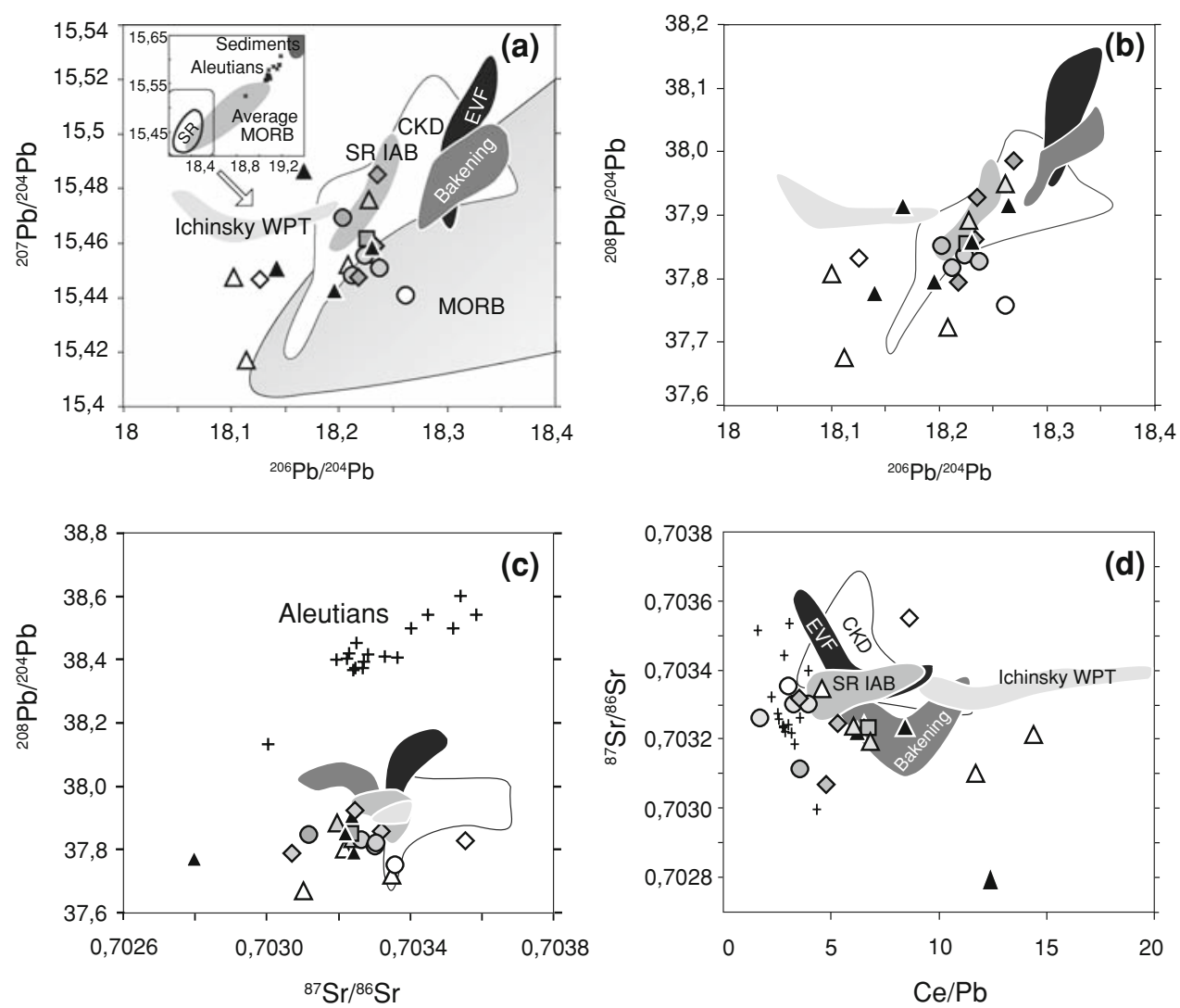

Pleistocene-Holocene monogenetic cones and stratovolcanoes and groups 3 and 4: underlying Late MiocenePliocene plateau. These two types of different age are compositionally uniform but significant differences exist between them (highly depleted N-MORB mantle source with low $\mathrm{Ta} / \mathrm{Yb}, \mathrm{Zr} / \mathrm{Sm}, \mathrm{Zr} / \mathrm{Y}$ and high $\mathrm{Ba} / \mathrm{Nb}, \mathrm{U} / \mathrm{Nb}$, Th/ Ta in groups 3 and 4 vs. variably enriched mantle source with high $\mathrm{Ta} / \mathrm{Yb}, \mathrm{Zr} / \mathrm{Sm}, \mathrm{Zr} / \mathrm{Y}$ and low $\mathrm{Ba} / \mathrm{Nb}, \mathrm{U} / \mathrm{Nb}$, Th/ Ta in groups 1 and 2). The SR rocks of different ages thus have rather variable geochemistry and significant variation in HFSE and fluid-mobile element contents at quite similar isotopic composition. They also differ in their morphology (plateau vs. monogenetic cones or stratovolcanoes) and erupted volumes. Sampling of rocks of preferably basaltic composition and the use of incompatible element ratios allows us to exclude possible effects of fractionation processes, and our choice of samples with most diverse compositions for isotope analysis should cover all variations in the potential magma sources: (a) mantle, depleted to a different degree by previous melting events; (b) enriched mantle; (c) subducted sediments; (d) assimilated crustal material; (e) partial slab melts (so-called "adakite component"), and (f) slab fluids generated by dehydration of the subducted oceanic crust (McCulloch and Gamble 1991; Sun and McDonough 1989; Hofmann 1988; Pearce and Parkinson 1993; Ayers 1998; Plank and Langmuir
1988; Poli and Schmidt 2002; Münker et al. 2004). We will discuss these potential components below.

Mantle source compositions

In determining the composition of the mantle source of our magmas, we followed the idea of McCulloch and Gamble (1991) that in a steady-state melting regime, the slab is required to supply the dominant proportion of LILE and lesser amounts of LREE, while HFSE and HREE are derived predominantly from the mantle, depleted to a different degree by previous melting events and partly replenished by asthenospheric flow. The method of calculating the mantle composition before its enrichment by a subduction component is based on the assumption that transport of HFSE and HREE in the slab fluid is limited (Pearce 1983; Pearce and Parkinson 1993). Such conservative behavior of HFSE during subduction in Kamchatka rocks was confirmed by high precision HFSE and $\mathrm{Hf}-\mathrm{Nd}$ isotope measurements (Münker et al. 2004). However, it has been argued (Kessel et al. 2005) that under high-P/ high-T conditions in deep slabs, a composite supercritical fluid may be responsible for elevated HFSE in (back-) arc settings. Here, however, low (MORB-like) Nd- and Sr-isotopic ratios in $\mathrm{SR}$ rocks and the absence of any correlation between radiogenic isotopes and enriched slab 
signatures prevent significant sediment involvement in magma genesis. Moreover, $\mathrm{Nb}$ and $\mathrm{Ta}$ concentrations in most enriched lavas from our collection are so high (26 and $1.6 \mathrm{ppm}$, respectively) that-in absence of an OIB-type mantle component-we should assume that about $90 \%$ of these elements (i.e. $23 \mathrm{ppm} \mathrm{Nb}$ and $1.4 \mathrm{ppm} \mathrm{Ta}$ ) would have to be transported with such a supercritical component, which we consider unrealistic. Therefore, a mantle source composition can be constructed by interpolating between HFSE and HREE on a "spider-diagram" (Fig. 9, dotted line). Based on existing data on mineral-melt distribution coefficients (Rollinson 1993; White 2000; Green et al. 2000; Zack et al. 1997; Gregorie et al. 2000; Kennedy et al. 1993; Ionov et al. 1997; LaTourrette et al. 1995; Foley et al. 1996; Johnson 1998; Hauri et al. 1994; Hart and Dunn 1993; many others) and mantle mineralogy (Koloskov 1999; Jagoutz et al. 1979; etc., see Table 4), we calculated the composition of the mantle wedge before fluid addition, so as to get a best fit of approximated and modeled trace element distribution patterns. The degree of melting was estimated using $\mathrm{Na}_{2} \mathrm{O}_{6.0}-\mathrm{CaO}_{6.0}$ systematic (Plank and Langmuir 1988) and HREE content. Our data, when plotted on a $\left(\mathrm{Na}_{2} \mathrm{O}\right)_{6.0}$ versus $(\mathrm{CaO})_{6.0}$ diagram, fall on the Plank and Langmuir (1988) trend of decreasing $\mathrm{CaO}$ and increasing $\mathrm{Na}_{2} \mathrm{O}$ at decreasing melting degree. Most old plateau lavas have $\mathrm{CaO}$ from 9.07 to 10.77 wt. $\%$ at $\mathrm{Na}_{2} \mathrm{O}$ 3.01-2.10 wt.\% (melting degree about $17-20 \%$ ), while younger rocks tend to group at the lower right part of the diagram with $\mathrm{CaO}$ 7.41-9.10 wt.\% and $\mathrm{Na}_{2} \mathrm{O}$ 4.233.42 wt. $\%$ (melting degrees $10-15 \%$ and lower). These rough estimates will be refined by modeling of HREE behavior at different melting extents.

According to our modeling, the mantle source of Late Pleistocene-Holocene rocks of SR can be described as a mixture of variably depleted N-MORB-type mantle (spinel lherzolite), with different amounts of enriched OIB-type mantle (30-55\% garnet lherzolite, Fig. 9a, b) with degrees of melting between 8 and 10\%. All Late Miocene-Pliocene plateau basalts are most likely produced by relatively high degrees of melting (about 20\%) of only a strongly depleted N-MORB-type mantle for which we assume an amphibole harzburgite modal composition (Fig. 9d). In the AlnejChashakondzha area there were only few samples with $\mathrm{MgO}>4 \%$. Therefore, we chose the sample with the lowest $\mathrm{SiO}_{2}$ content as representative of the most primitive melt. The composition of the mantle source was calculated as a mixture of $86 \%$ depleted N-MORB-type mantle (spinel lherzolite) and $14 \%$ enriched OIB-type mantle at $10 \%$ melting (Fig. 9c). Our model implies an amphibole-bearing residue after melting. Preliminary temperature estimates limited to a few samples (Volynets unpublished) are relatively high $\left(>1,100^{\circ} \mathrm{C}\right.$ for some rocks) but inconclusive with respect to differences between the magmatic

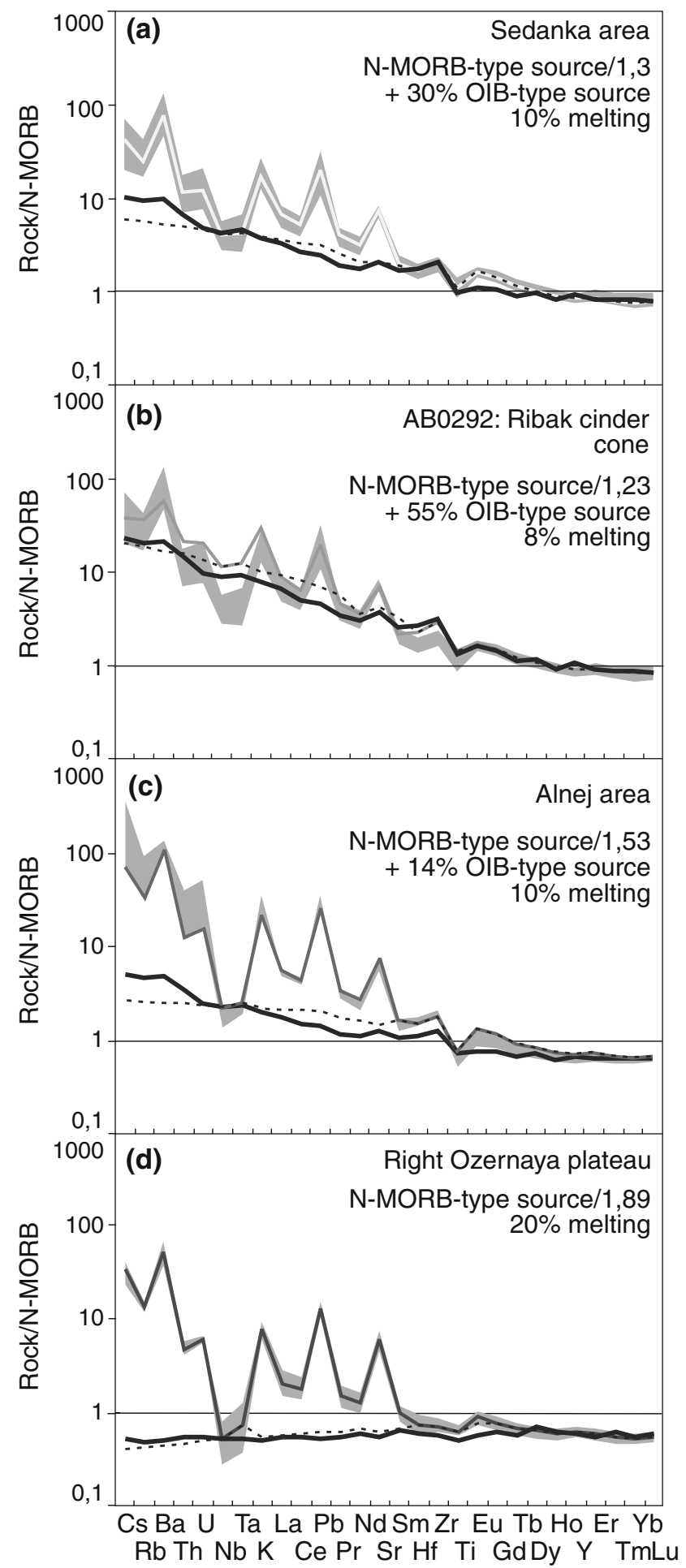

Fig. 9 Modeled source compositions before slab fluid addition in comparison with the actual rock compositions. Dotted line: composition of mantle before fluid addition (after Pearce 1983; Pearce and Parkinson 1993) based on the relative compatibility of the trace elements. Bold black line: modeled mantle source composition. gray field: reference for all volcanic rocks from the studied area; gray linecomposition chosen for geochemical modeling. All data are normalized to N-MORB (Sun and McDonough 1989). The amounts of each component and degree of melting from the model is given in insets 
temperatures for different age groups. If confirmed, these high temperatures would place the mantle source at the uppermost limit of amphibole stability in the mantle wedge (Foley 1991; Fumagalli and Poli 2005; Niida and Green 1999; Schmidt and Poli 1998; Wallace and Green 1991).

Our interpretation supports an OIB-type mantle component (Volynets 1994; Churikova et al. 2001, 2007; Münker et al. 2004); however, different mantle sources are evident in slightly variable isotopic compositions for only a few samples (Fig. 7). The HREE-depletion in Kamchatka arc rocks relative to N-MORB source was proposed to be a result of formation of older voluminous plateau basalt magmatism (Churikova et al. 2001; Münker et al. 2004). However, we observe that mantle sources of these Late Miocene-Pliocene plateau basalts (LOP and ROP) already had extremely depleted HFSE and HREE ( $\mathrm{Yb}_{\text {sample }} / \mathrm{Yb}_{\mathrm{N}}$ MORB between 0.46 and 0.78 ). This leads us to the conclusion that the melting event that caused a regional depletion of the mantle wedge below the Kamchatka back arc likely occurred prior to formation of the Late Miocene plateau basalts.
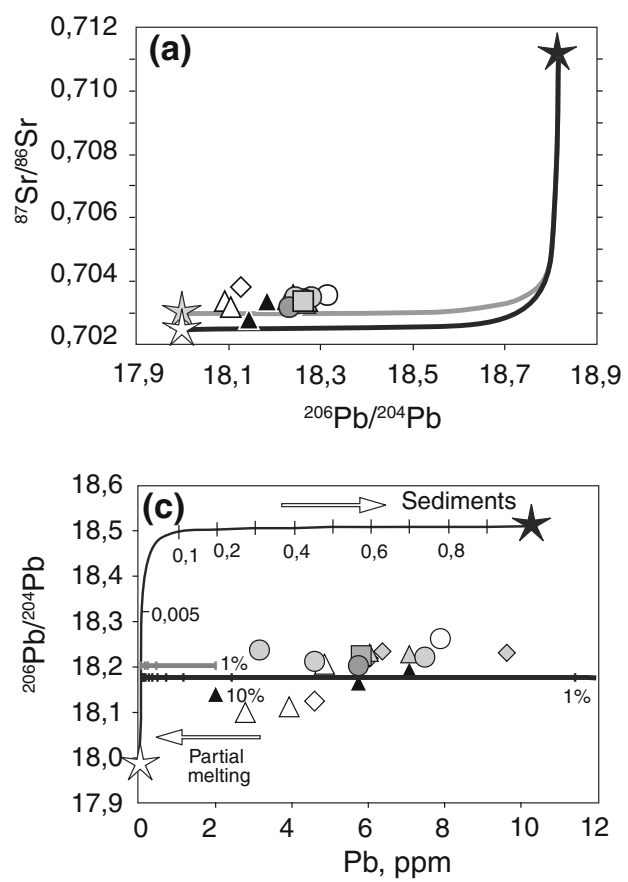

Fig. 10 Schemes of mixing between N-MORB source and sediment, defined by strontium and lead isotopic compositions and concentrations of these elements in the end-members; SR volcanic rocks data are plotted for comparison. Black star: average Pacific sediment composition. White star: average N-MORB composition. a Black line indicates mixing curve between average N-MORB and average Pacific sediment. Gray star on the background and gray curve correspond to $\mathrm{N}-\mathrm{MORB}$ with an elevated $\mathrm{Sr}$ isotope ratio of ${ }^{87} \mathrm{Sr} /{ }^{86} \mathrm{Sr}=0.703$, representing N-MORB + seawater, and relevant mixing curve between this MORB and sediment. Our data plot near this second mixing curve. b Mixing curve, calculated for Sr isotopes and $\mathrm{Sr}$ concentrations in end-members, and modeled partial melting
The outcome of our model is to some extend dependent on the choice of end-members and modeling parameters (composition, partition coefficients, and modal mineralogy of the source). We selected mantle source compositions and distribution coefficients, which allowed us to get the results closest to the observed values. For example, the OIB-like mantle source cannot be replaced by a less depleted mantle as proposed for Karymsky lavas (Portnyagin et al. 2007a), because HFSE contents would remain too low. Other partition coefficients (e.g. Workman and Hart 2005) for modeling the most enriched sample AV0292 resulted in slightly lower concentrations for most of elements in the modeled mantle source (difference is $<4.2 \%$ ), a higher OIB contribution (65\% instead of 55\%) and higher degrees of melting (11\% instead of $8 \%)$. For the most depleted samples, the difference between two models in element concentrations would be higher and to achieve the better match with the real rock composition it would require to apply lower degrees of mantle melting. In any case, the inferred temporal variation in source composition is robust and does not depend critically on the modeling parameters.
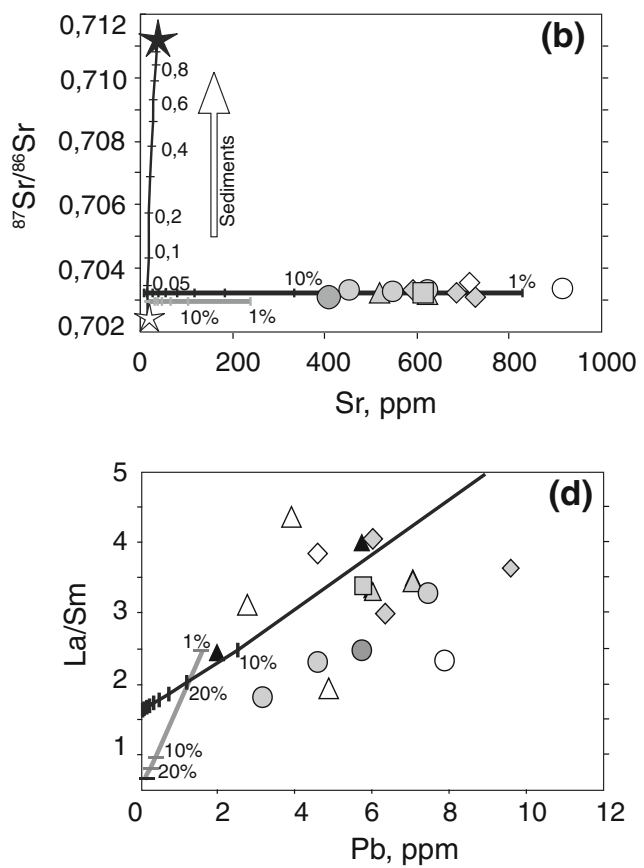

line for the mix (gray line with indication of melt amount) and modeled partial melting line for the mix of N-MORB and subduction fluid (black line with indication of melt amount). Composition of the subduction fluid is after (Stolper and Newman 1994). c modeled mixing curve, calculated for $\mathrm{Pb}$ isotopes and $\mathrm{Pb}$ concentrations in the end-members, modeled partial melting of the mix (gray line) and modeled partial melting for the mix of N-MORB and subduction fluid (black line). d La/Sm vs. $\mathrm{Pb}$ (ppm) for the samples, analyzed for isotopic composition and modeled mixing curves for the partial melting of the mix of NMORB-source and sediment melt (gray line) and mix of NMORB-source and subduction fluid (black line). For further discussion see text 
Sediments and crust contamination

Pelagic sediments and their melts have high $\mathrm{Pb}$ - and $\mathrm{Sr}$ concentrations and isotopic ratios (average ${ }^{206} \mathrm{~Pb} /{ }^{204} \mathrm{~Pb}$ $\sim 18.8 ;{ }^{87} \mathrm{Sr} /{ }^{86} \mathrm{Sr} \sim 0.711$, Plank and Langmuir 1998). The addition of $<1 \%$ amount of sediments to the mantle source, therefore, will cause a strong increase of isotope ratios in comparison with "pure" MORB mantle (Fig. 10). Since all our samples are very low in $\mathrm{Sr}-$ and $\mathrm{Pb}$ - and high in $\mathrm{Nd}$-isotopes (i.e. close to MORB mantle), there is no evidence for a significant sediment involvement in magma generation in the Kamchatka back arc.

This conclusion is in agreement with previously published data based on $\mathrm{Pb}$ and $\mathrm{Be}$ isotope data (Kersting and Arculus 1995; Churikova et al. 2001; Tsvetkov et al. 1989, etc.). Unradiogenic $\mathrm{Sr}$ isotope ratios also preclude significant assimilation of old continental crust in Kamchatka magmas, in particular for the most mafic rocks (Churikova et al. 2001).

An adakite component in SR magmas?

Participation of slab melts in magma generation would result in high $\mathrm{Sr} / \mathrm{Y}(\mathrm{Sr} / \mathrm{Yb})$ and $\mathrm{La} / \mathrm{Yb}$ ratios and increased silica content at higher $\mathrm{Mg}$ concentrations. Due to the strong preference for HREE by garnet in the residue after melting of the subducted oceanic basalts, a significant LREE/HREE enrichment would be expected and be coupled to depletion in HREE (Fig. 11), which is not observed. Thus, an adakite component (i.e. slab melts) can be excluded from the discussion.

\section{Composition and amounts of slab fluids}

According to the recent data on mineral-melt-fluid distribution coefficients (Ayers 1998; Brenan et al. 1995; Keppler 1996; Stalder et al. 2001; Kessel et al. 2005) slab fluids should be enriched in LILE ( $\mathrm{K}, \mathrm{Cs}, \mathrm{Rb}, \mathrm{Ba}, \mathrm{Pb}$ ), to a lesser extent-LREE, and depleted in HFSE ( $\mathrm{Nb}, \mathrm{Ta}, \mathrm{Zr}$, Hf), Th and HREE (Gill 1981; Tatsumi et al. 1995; Churikova et al. 2001). U, Ba, Th, $\mathrm{Pb}$ are easily transported in fluids, while $\mathrm{Nb}, \mathrm{Ta}$, and $\mathrm{Ce}$ are much less soluble. Both element groups, however, should behave similarly during crystal-melt equilibration. Therefore, $\mathrm{Ba} / \mathrm{Nb}, \mathrm{Th} / \mathrm{Ta}, \mathrm{U} / \mathrm{Nb}$, $\mathrm{Pb} / \mathrm{Ce}$ ratios do not vary during partial melting but should increase with minor fluid involvement. In the more depleted mantle source, less fluid is needed to elevate these ratios. To estimate the fluid composition and to distinguish the relative contribution of each element by mantle source and subduction component, we first added variable amounts of a fluid component to all modeled mantle compositions. The fluid composition was mostly based on Stolper and Newman (1994), only $\mathrm{Ba}, \mathrm{Nb}$, and $\mathrm{Pb}$

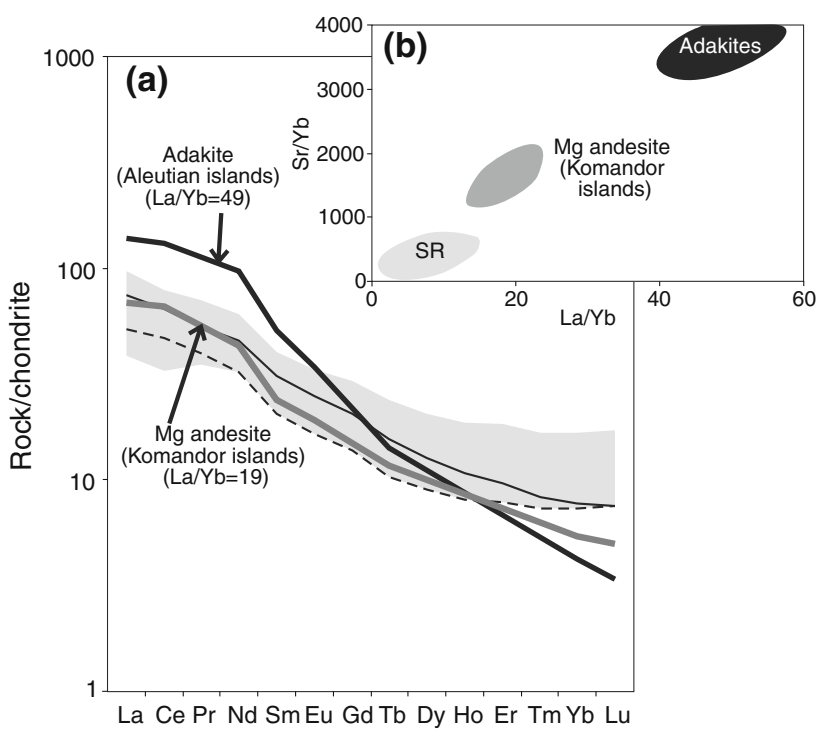

Fig. 11 Comparison of trace elements and REE in Aleutian adakites, Komandor Mg-andesites and SR rocks, studied here (gray field). a REE distribution patterns for compared rocks. Concentrations are normalized to $\mathrm{C} 1$ chondrite (Sun and McDonough 1989). Black thin line TT-1019/2 sample (Tekletunup area), black dotted line 293/1 sample (Chashakondzha area). b $\mathrm{Sr} / \mathrm{Yb}$ vs. $\mathrm{La} / \mathrm{Yb}$ in compared rocks. Typical adakites, as well as $\mathrm{Mg}$ andesites from Komandor islands with slab melt in their source, have much higher $\mathrm{Sr} / \mathrm{Yb}$ and $\mathrm{La} / \mathrm{Yb}$ then all studied SR rocks. Composition of Aleutian adakites and Komandor andesites after Yogodzinski et al. (1995)

concentrations are taken from Brenan et al. (1995). For a detailed description of the calculation method, see Churikova et al. (2001). This fluid-modified source was then batch-melted to different degrees, using an amphibolebearing mantle. The amount of fluid and the melting degree was adjusted individually in each case to get maximal agreement with observed whole rock-concentrations for most fluid-mobile elements, as $\mathrm{Rb}, \mathrm{K}, \mathrm{Ba}, \mathrm{Sr}$, and $\mathrm{Pb}$ (Fig. 13). An example of this step of the modeling is represented in Fig. 12, for model parameters, see Table 5.

Calculated compositions are usually over-enriched in $\mathrm{Y}$, $\mathrm{Zr}, \mathrm{Nb}$, and $\mathrm{Ta}$ compared to observed compositions. This difference is less pronounced in models for compositions that include an OIB component, due to the lesser amount of the fluid involved in their genesis and higher HFSE concentrations in the OIB component. The composition of fluids in all rocks is rather similar. However, in detail, we see that HFSE and LREE elements are elevated in all Late Pleistocene-Holocene lavas compared to Late MiocenePliocene plateau basalts. At the same time, LILE are more enriched in the depleted rocks of Late Miocene-Pliocene age and show similarity to the lavas from the recent arc front.

Our approach assumes that the difference between the modeled mantle wedge base line and observed whole-rock 


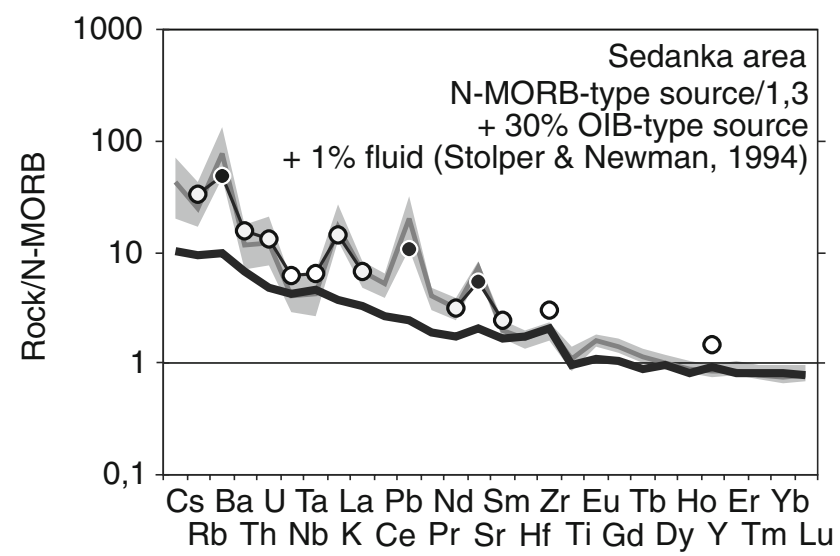

Fig. 12 Calculated mixtures of the modeled mantle source (bold line) and slab fluid after (Stolper and Newman 1994) for Sedanka area (black line with circles). Relative amounts of each component are shown in the right upper part of the diagram. Elevated $\mathrm{Nb}, \mathrm{Ta}, \mathrm{Zr}, \mathrm{Y}$ concentrations in the fluid are shown by white circles; low $\mathrm{Ba}, \mathrm{Pb}, \mathrm{Sr}$ concentrations-black circles; gray line-modeled rock composition

composition is a result of fluid addition. Given that little is known about HFSE and HREE behavior in the fluid phase at high pressures and temperatures, the concentrations of HFSE elements in our model are somewhat arbitrary. Recent investigations of trace element behavior at high pressures show that at pressures equivalent to $180 \mathrm{~km}$ depth a supercritical liquid with melt-like solubility is observed, mobilizing most of the key trace elements (Kessel et al. 2005). On the basis of high-precision measurements of HFSE in Kamchatka volcanic rocks, (Münker et al. 2004) concluded that while $\mathrm{Lu}, \mathrm{Zr}$, Hf behave conservatively, $\mathrm{Nb}$ and $\mathrm{Ta}$ may be transported by subduction fluids, but the amount added is insignificant with respect to the overall mass balance. Probably, HREE and HFSE can be partitioned to the fluid to some (although not substantial) amounts under Kamchatka back-arc conditions, where this deep fluid is possibly silicarich and more readily dissolving these elements (Keppler 1996; Stalder et al. 2001; Churikova et al. 2007). Th levels are relatively uniform for rocks of highly variable $\mathrm{Nb}$ and Ta. If a "dense" fluid were significantly involved rather than an enriched (OIB-) mantle component, it would be hard to explain that only $\mathrm{Nb}$ and $\mathrm{Ta}$ are carried by this fluid and $\mathrm{Th}$ is not. In general, Sredinny Range fluids demonstrate not only internal conformity but also are also similar to fluids that were calculated for the EVF and CKD Kamchatka lavas by Churikova et al. (2001). Substantial differences, as originally seen in distinct whole-rock compositions, are observed only for the most fluid-mobile element concentrations and their ratios-K/La, Cs/Rb, Ba/Th (Fig. 14). Cs concentrations in EVF fluids are much higher due to its particularly high mobility in fluids and the proximity of the EVF to the trench. Fluids in Late Miocene-Pliocene plateau magma sources of Group 3 are equally enriched in all these ratios, lower in $\mathrm{Ce} / \mathrm{Pb}$ compared to Late Pleistocene-Holocene monogenetic lavas, and thus are similar to fluids involved in EVF magma genesis. Samples from Left Ozernaya River rocks of Group 4 show very similar composition to Group 3 but are distinct only for some of the most fluid-mobile elements (e.g. Cs, Mo). Noll et al. (1996), Hattori and Guillot (2003) and Wörner et al. (2001) used the observation that chalcophile and siderophile elements are even more readily partitioned into a fluid and therefore can even better constrain fluid involvements. Rocks of the first group are rather low in $\mathrm{Sb} / \mathrm{Ce}$ ratio, probably due to the low amount of fluids in their source. Left Ozernaya River plateau again show lower values of $\mathrm{Sb} / \mathrm{Ce}$ at higher $\mathrm{Ba} / \mathrm{Nb}$ than in lavas of Group 3. These data suggest that all Late Miocene-Pliocene plateau lavas were formed from the same depleted N-MORB mantle source but were influenced by fluids of slightly different composition.

The amounts of fluid and OIB components in the source are correlated with the age of the rocks studied. Late Pleistocene and Holocene volcanic rocks (Group 1 and 2) have higher amounts of enriched mantle component in their source (14-55\%); they also have relatively small estimated fluid additions to their sources (0.4-2\%). Late MiocenePliocene lava flows and plateau basalts (Groups 3 and 4) do not have an OIB-type component in their source and have higher apparent fluid additions to their sources $(1.5-4 \%$; on average more than $2 \%$ ). These rocks are also produced by higher degrees of partial melting (up to $20 \%$ in comparison with $8-10 \%$ for Late Pleistocene-Holocene rocks). In addition, they have a different mantle source mineralogy (harzburgite for LOP instead of lherzolite for the majority of SR rocks).

These observations lead us to two main conclusions with respect to mantle sources and fluids. First, the subducted slab plays an important role in Kamchatka back-arc magmatism, also at its northern end, where no active subduction can be traced by geophysical methods (Davaille and Lees 2004). In addition, we should not underestimate the importance of the enriched mantle component in producing back-arc magmas, without an OIB component many geochemical features of Late Pleistocene-Holocene volcanic rocks would be difficult to explain.

A second important observation is the similarity of slab fluid composition in rocks for all age groups for the whole Sredinny Range. Even though we found subtle differences (see above), the modeling results are quite robust: slab fluids in all Late Pleistocene-Holocene volcanic rocks are relatively enriched (i.e. less depleted) in HFSE and LREE and have similar overall patterns compared to the fluids in Late Miocene-Pliocene plateau lavas. This suggests that surprisingly similar fluids segregated from the same Pacific Plate below the arc front during the Late Miocene-Pliocene and the back-arc in the Quaternary. 
Fig. 13 Modeled fluid compositions for SR rocks in comparison with EVF, CKD and Ichinsky WPT fluids, from this study and from Churikova et al. (2001). Gray reference field corresponds to the entire modeled fluid compositions for all SR rocks from this study. Concentrations are normalized to N-MORB (Sun and McDonough 1989)

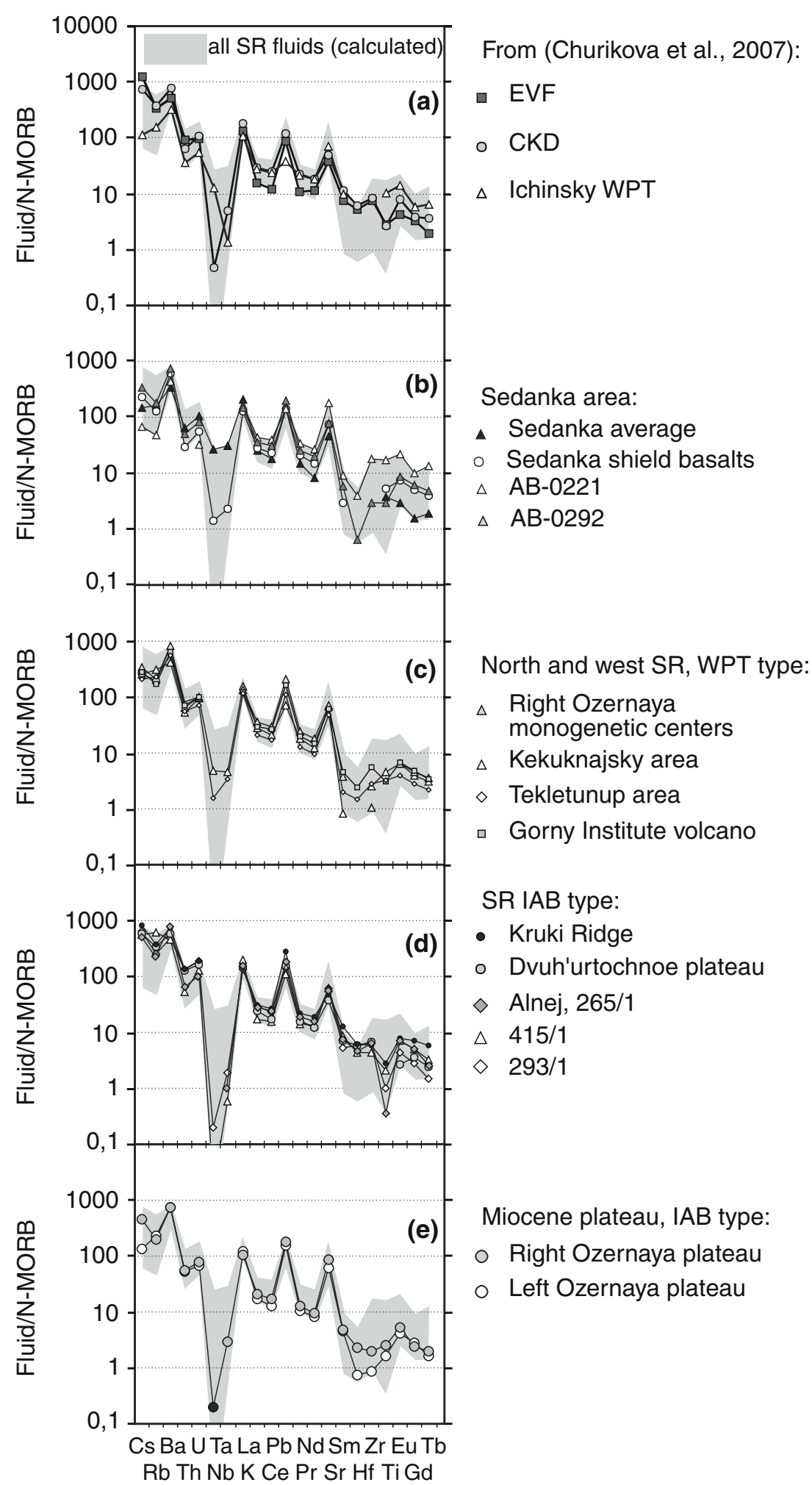

The origin of plateau lavas and recent volcanism at the Sredinny Range

As known from geological and geophysical studies (Legler 1977; Lander and Shapiro 2007; Avdejko et al. 2002;
Alexeiev et al. 2006), the active volcanic front of the ProtoKamchatka subduction zone was located in Eocene-Miocene times in the present position of the Sredinny Range. Later, the Kamchatka arc system has been modified by stepwise accretion from south to north of the Kronotsky 
Table 4 Partition coefficients, used for modeling in this work

\begin{tabular}{lllllll}
\hline & Ol & Opx & Cpx & Amf & Gt & Sp \\
\hline $\mathrm{Cs}$ & 0.0015 & 0.001 & 0.0039 & 0.1 & & \\
$\mathrm{Rb}$ & 0.0013 & 0.0026 & 0.0033 & 0.4357 & 0.007 & 0.0454 \\
$\mathrm{Ba}$ & 0.0005 & 0.0008 & 0.0022 & 0.282 & 0.0007 & 0.0052 \\
$\mathrm{Th}$ & 0.006 & 0.0056 & 0.014 & 0.0149 & 0.0014 & 0.0023 \\
$\mathrm{U}$ & 0.0182 & 0.005 & 0.013 & 0.01 & 0.0059 & \\
$\mathrm{Nb}$ & 0.00005 & 0.001 & 0.0081 & 0.1232 & 0.0538 & 0.0128 \\
$\mathrm{Ta}$ & 0.00005 & 0.015 & 0.013 & 0.0517 & 0.11 & 0.0492 \\
$\mathrm{~K}$ & 0.00017 & 0.0001 & 0.0028 & 0.35 & 0.002 & \\
$\mathrm{La}$ & 0.0017 & 0.0015 & 0.052 & 0.0893 & 0.0164 & 0.01 \\
$\mathrm{Ce}$ & 0.0009 & 0.0051 & 0.108 & 0.0986 & 0.065 & 0.0081 \\
$\mathrm{~Pb}$ & 0.0076 & 0.0121 & 0.01 & 0.2171 & 0.0001 & 0.0796 \\
$\mathrm{Pr}$ & 0.000049 & 0.0069 & 0.14 & 0.178 & 0.0072 & 0.01 \\
$\mathrm{Nd}$ & 0.0059 & 0.004 & 0.277 & 0.1349 & 0.363 & 0.0006 \\
$\mathrm{Sr}$ & 0.0075 & 0.15 & 0.157 & 0.1813 & 0.0099 & 0.0441 \\
$\mathrm{Sm}$ & 0.000445 & 0.0037 & 0.462 & 0.18 & 1.1 & 0.0064 \\
$\mathrm{Hf}$ & 0.001 & 0.041 & 0.223 & 0.1144 & 1.22 & 0.05 \\
$\mathrm{Zr}$ & 0.019 & 0.038 & 0.195 & 0.1113 & 2.12 & 0.184 \\
$\mathrm{Ti}$ & 0.015 & 0.1933 & 0.347 & 1.3 & 0.29 & 0.8363 \\
$\mathrm{Eu}$ & 0.0016 & 0.0078 & 0.458 & 0.88 & 0.32 & 0.0859 \\
$\mathrm{Gd}$ & 0.01 & 0.0726 & 0.4 & 0.2027 & 0.61 & 0.01 \\
$\mathrm{~Tb}$ & 0.0036 & 0.011 & 0.42 & 0.779 & 1.03 & 0.0078 \\
$\mathrm{Dy}$ & 0.007 & 0.0522 & 0.711 & 0.2428 & 2.2 & 0.0015 \\
$\mathrm{Ho}$ & 0.00927 & 0.019 & 0.66 & 0.783 & 1.53 & 0.01 \\
$\mathrm{Y}$ & 0.0098 & 0.014 & 0.467 & 0.634 & 2.8 & 0.01 \\
$\mathrm{Er}$ & 0.0261 & 0.0542 & 0.259 & 0.46 & 2 & 0.003 \\
$\mathrm{Tm}$ & 0.009 & 0.025 & 0.633 & 0.64 & 3 & 0.01 \\
$\mathrm{Yb}$ & 0.036 & 0.22 & 0.43 & 0.59 & 3.88 & 0.0076 \\
$\mathrm{Lu}$ & 0.05 & 0.22 & 0.623 & 0.51 & 3.78 & 0.01 \\
\hline $\mathrm{Refe}$ & & & & & &
\end{tabular}

References

Ol, Opx: White (2000), Rollinson (1993), Gregorie et al. (2000), McKenzie and O'Nions (1991), Nikogosian and Sobolev (1997), Frey (1969), Nielsen et al. (1992), Bedard (1994), Ayers (1993)

Cpx: White (2000), Zack et al. (1997), Green et al. (2000), Sobolev et al. 1996, Hauri et al. (1994), Johnson (1994), Hart and Dunn (1993)

Amf: White (2000), Gregorie et al. (2000), McKenzie and O'Nions (1991), LaTourrette et al. (1995), Halliday et al. (1995), Kelemen et al. $(1990,1993)$

Gt: Garnet: Zack et al. (1997), Johnson (1994, 1998), McKenzie and O'Nions (1991), White (2000), McKenzie and O'Nions (1991), Hauri et al. (1994)

Sp: White (2000), McKenzie and O’Nions (1991), Gregorie et al. (2000)

terrains (Fig. 16 in ESM) between 40 and 2 Ma (Alexeiev et al. 2006; Lander and Shapiro 2007).

Our data constrain the style of magmatism with respect to these tectonic events. The systematic change in SR rock geochemistry with time is interpreted as the result of this arc shift and a massive slab rollback as suggested by tectonic reconstructions. In this scenario, the SR represented the active volcanic front until $\sim 3$ Ma with voluminous plateau basalts derived from an extremely depleted $\mathrm{N}$ MORB-like mantle source and high degrees of melting. The geochemical uniformity of this first group, also in comparison to the composition of modern arc-front magmas, suggests that the same processes and sources were involved.

Since the arc-front shifted trench-ward, the SR represents the modern back arc region. This is confirmed by the continuous geochemical zonation from arc front to back arc at the latitude of Ichinsky volcano, i.e. strong and gradual increase in LILE, LREE, and HFSE (Churikova et al. 2001, 2007). The younger group (Late Pleistocene-Holocene) is characterized by low-degree melting of a partly enriched (OIB-) mantle. The geochemical uniformity of all Late Pleistocene-Holocene volcanic rocks of the SR again suggests that these rocks were essentially formed from the same sources. Comparing the two groups, we found systematic differences in the composition of the mantle wedge; however, relative to larger variations in other arcs, these differences are comparatively small. To explain this relative homogeneity, we argue that volcanism in the northern part of the SR was mainly caused by large degrees of fluid-induced melting with slab fluids dominating the element budged while a significant sediment component is absent.

Compared to the volcanic front, mantle upwelling from the deep asthenospheric wedge must have aided melting in the back arc and the incorporation of the enriched OIB mantle components. Therefore, we suggest a general trend from fluid-dominated melting in the Eastern Volcanic front, to upwelling of a strongly fluid-fluxed mantle below the Central Kamchatka Depression (Dorendorf et al. 2000b) to melting of a fluid-enriched mantle aided by strong upwelling and decompression in the back arc region.

The nature of the northern termination of arc and back arc magmatism in Kamchatka

Geophysical research of the Kurile-Kamchatka triplejunction and Aleutian island arcs shows that the maximum depth of seismicity decreases from south to north below Kamchatka and seismic data do not show a clear signal for a down going oceanic plate below the northern part of the SR despite the fact that voluminous recent magmatism is observed (Pevzner and Volynets 2006). It has been shown by Kirby et al. (1996), however, that seismicity is lost at slab temperatures higher than $600-700^{\circ} \mathrm{C}$ due to its increasingly ductile behavior. Davaille and Lees (2004) also argued that the seismicity of the subducted Pacific slab is gradually decreasing to the north as result of slab edge heating in the mantle wedge and mostly due to a decreasing plate thickness. Moreover, the rate of subduction under 


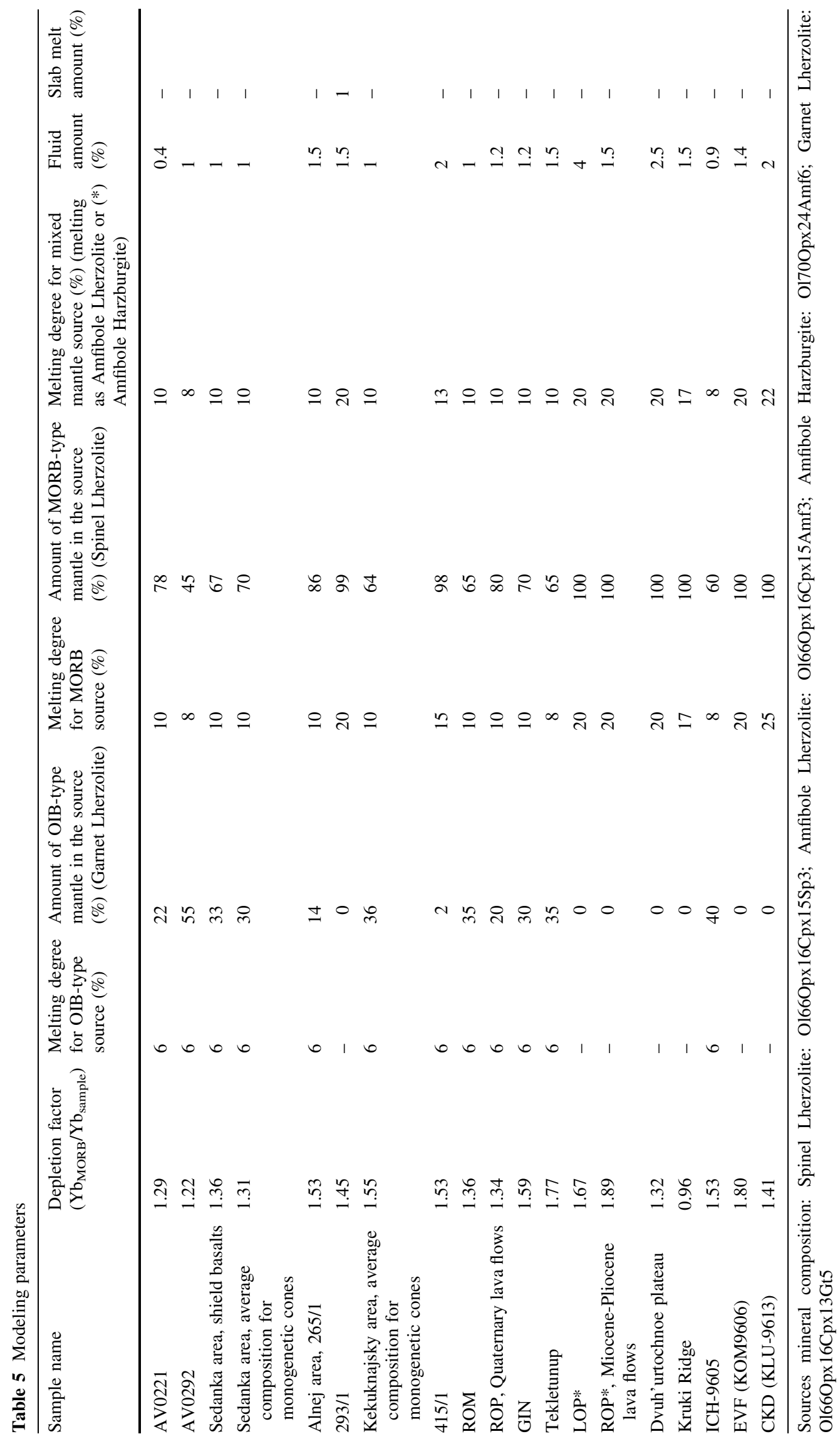


Kamchatka across the Aleutian-Bering-Alfa fault zone from the active Pacific Plate to the stable Bering Sea Plate decreases from $8 \mathrm{~cm} /$ year to nearly nil, causing the increased heating of the lower velocity slab. Yogodzinski et al. (2001) argued that the edge of the Pacific Plate is traced below Shiveluch volcano while Portnyagin et al. (2005) show that slab edge may be further $\mathrm{N}$ and is marked by the Shisheisky complex (about $80 \mathrm{~km} \mathrm{~N}$ of Shiveluch volcano, Fig. 15).

Some information on the northern edge of the Pacific Plate and its border with the Bering Sea Plate is gained by the morphology of the down going oceanic plate (Baranov et al. 1991; Seliverstov 1998; Fig. 15) in the region of the triple junction, where this border is represented by a $150 \mathrm{~km}$ wide zone from the Aleutian- through Bering- to Alfa-transform faults. Based on the projected continuation of these faults under Kamchatka, we argue that the northern termination of the subducted Pacific Plate probably is not a single abrupt plate edge but rather is represented by a wide zone with segments separated by transform faults. Magmas with somewhat higher $\mathrm{Sr} / \mathrm{Y}$ ratios were found at Shiveluch volcano and on the Shisheisky complex (Yogodzinski et al. 2001; Portnyagin et al. 2005) and were interpreted to result from a slab melt with a garnet residue derived from the heated slab edge at the northern slab termination. However, Holocene volcanism at this northern termination in the back arc does not show such an effect and this slab edge effect is weak at best in the volcanic front.

The en-echelon offset of the northern termination of Holocene volcanism to the $\mathrm{N}$ from the Eastern Volcanic Front to the Central Kamchatka Depression and the Sredinny Range probably better traces the slab edge. As no volcanoes of Holocene age are found north of the projection of the Alfa-fault, there is probably no active subduction to the $\mathrm{N}$ of the on-land projection of this transform.

With increasing depth, the melting regime may be increasingly modified by segmentation of the slab and mantle movement across the direction of the main vector of subduction (Davaille and Lees 2004) and thus magmatism will provide only a diffuse image of the slab edge in the back arc.

\section{Conclusions}

1. The rocks of the Sredinny Range are distinguished in terms of their morphology, geochronology, and geochemistry in two groups. The first group of Late Miocene-Pliocene age (3-6 Ma) represents voluminous plateau lavas derived from a highly depleted mantle source with substantially low HFSE and HREE and high fluid-mobile enrichments. The second group
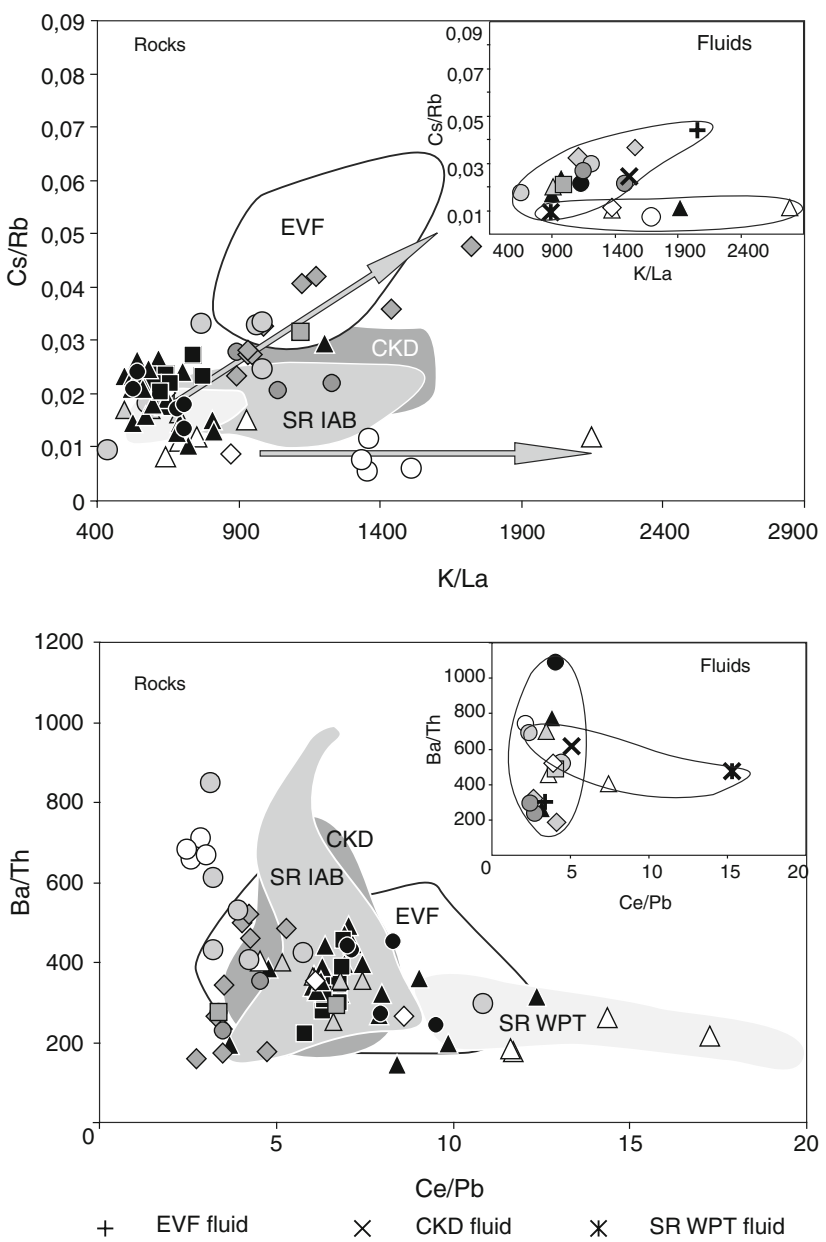

Fig. $14 \mathrm{Cs} / \mathrm{Rb}$ versus $\mathrm{K} / \mathrm{La}$ and $\mathrm{Ba} / \mathrm{Th}$ versus $\mathrm{Ce} / \mathrm{Pb}$ for volcanic rocks from Kamchatka and for calculated fluids (insets in the upper right part of diagrams). Symbols are as in Fig. 3. Fields correspond to Kamchatka rock compositions for reference (Churikova et al. 2001; Dorendorf et al. 2000a, b). For discussion see text

of Late Pleistocene-Holocene age (less than $1 \mathrm{Ma}$ ) are mostly monogenetic cones and stratovolcanoes that combine a subduction- with a within-plate-type signature with variable enrichment in all incompatible elements. Despite obvious differences between the two groups, all rocks belong to medium-high-K calcalkaline series and are characterized by rather similar subduction trace elements signatures and primitive isotopic composition.

2. Trace element patterns and isotope composition of volcanic rocks allow us to identify three components that contributed to magma generation in the Sredinny Range of Kamchatka: (1) N-MORB-type mantle, depleted to a different extent, (2) enriched OIB-type mantle, and (3) a slab fluid. While the Late MiocenePliocene plateaus were produced by high-percentage melting $(20 \%)$ of extremely depleted NMORB mantle, induced by large fluid addition, the Late Pleistocene- 


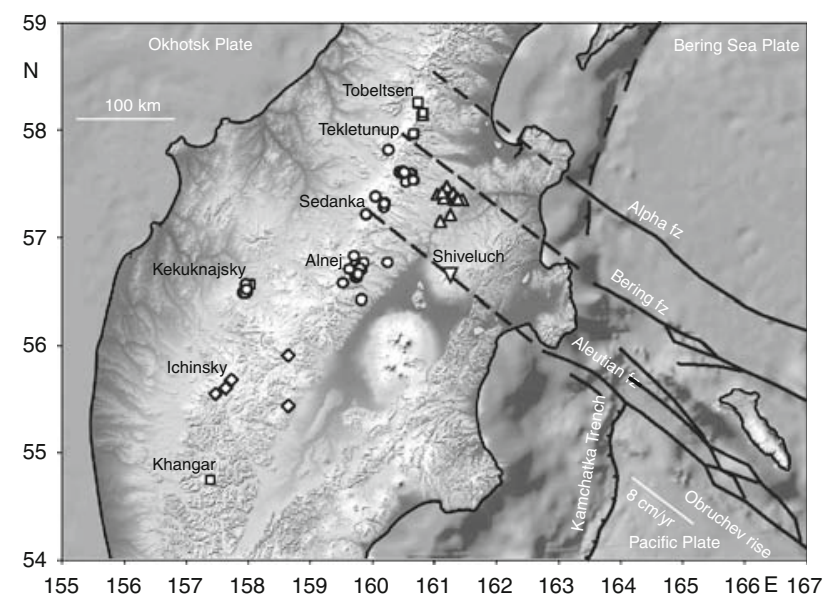

Fig. 15 Tectonic configuration of the region, where three plates are joined on the base of data received by R/V "Volcanolog" (Seliverstov 1998). Pacific Plate subducts under Okhotsk Plate with the velocity $8 \mathrm{~cm} /$ year, and forms Kamchatka Trench on the boundary of these two plates. This trench is represented on the figure by solid line with triangles showing the subduction direction. The trench of the ProtoKamchatka subduction zone is situated between the Bering Sea- and Okhotsk Plates and is shown by dotted line with triangles. Relative motion of Pacific Plate and Bering Sea Plate produces the system of the transform fault zones. It is possible to pick three main zones of this system: Aleutian trench, Bering transform fault, Alpha transform fault. These zones are represented by solid lines. Dotted lines show projections of these transform zones below the Okhotsk Plate. The data for Late Pleistocene-Holocene volcanism on the SR and on the north edge of the subducting Pacific Plate are represented by: upturned triangle-Shiveluch volcano (Yogodzinski et al. 2001), triangles-Shisheisky complex (Portnyagin et al. 2005), squaresdata from (Pevzner and Volynets 2006), and diamonds - data from Churikova et al. (2001). New data from this paper are marked by circles

Holocene volcanic rocks were formed by lower degrees of melting (8-10\%) from an enriched mantle source (average $70 \%$ variably depleted MORB $+30 \%$ OIB) and a smaller contribution from a slab fluid. Significant amounts of subducted sediments or their melts are notably absent in the magma source.

3. We argue that the systematic change in rock geochemistry at the same location is the result of the modification of the subduction setting of SR due to the shift of the subduction zone to the east during terrain accretion. The plateau lavas are in fact similar to the Kamchatka arc front lavas and represented the arc front at Miocene times. The overlying Quaternary rocks represent the modern back arc lavas to the presently active subduction zone.

4. Both, the uniform geochemistry of young volcanic rocks along the SR and the systematic across arc geochemical zonation from contemporary arc front to back arc indicates a trend from fluid-dominated melting in the Eastern Volcanic front, through the upwelling of a strongly fluid-fluxed mantle below the
Central Kamchatka Depression to melting of a fluidenriched mantle aided by strong upwelling and decompression in the present back arc region.

5. The northern edge of the subducting Pacific Plate is marked by the termination of Holocene volcanoes and is represented by a wide plate boundary transform fault zone. The absence of young volcanism in the Sredinny Range to the north of the on-land projection of the Alpha fault marks the plate boundary at depth.

Acknowledgments Pevzner M.M., Dirksen O.V., Portnyagin M., Puzankov M., Rodin V., Zubkov E. are specially thanked for the help and collaboration during field work and Pevzner M.M., Perepelov A.B. and Ladygin V.M. for providing additional samples. Help in the laboratory by K. Simon and G. Hartman, was instrumental in obtaining our data. Useful comments by Ponomareva V.V., Pevzner M.M., Babansky A.D. and discussions with Lander A.V., Lomize M.G., Shapiro M.N., Melekestsev I.V., Perepelov A.B. helped us to improve this manuscript. This work benefited greatly from thoughtful reviews of Bill Leeman and Leonid Danyushevsky. Oleg Volynets (deceased) inspired this study by generously sharing his enthusiasm for Kamchatka. This work was supported by a DAAD scholarship A/ 04/00138 and various other grants: FEB RAS 09-III-B-08-465, "Leading scientific schools" grants NSh-1618.2003.5, RI-112/001/ 610, RI-112.0/001/076, NSh-6722.2006.5 and Jack Kleinman Internship for Volcano Research-2002 to A.V., Russian Foundation for Basic Research grants № 03-05-65007, 96-05-65311, 99-0564954, 01-05-64998, 02-05-64991, 05-05-64776, 07-05-00536-a, 0805-00932-a and 08-05-00600-a, projects of "Program 13" of Russian Academy of Science Presidium, Ministry of Industry and Science projects № 43.700.11.0005, № 43.043.11.1606, State Contract with Federal Agency of Science and Innovations' Department of Survey and New Technologies Development № 01.700.12.0028 to T.C. and A.V., DFG Project Wo362/15-1 + 2 to G.W. and № 00-0504000 from the DFG-RFBR cooperation Program to T.C. and G.W.

Open Access This article is distributed under the terms of the Creative Commons Attribution Noncommercial License which permits any noncommercial use, distribution, and reproduction in any medium, provided the original author(s) and source are credited.

\section{References}

Alexeiev DV, Gaedicke C, Tsukanov NV, Freitag R (2006) Collision of the Kronotskiy arc at the NE Eurasia margin and structural evolution of the Kamchatka-Aleutian junction. Int J Earth Sci (Geol Rundsch) 95:977-993

Avdejko GP, Popruzhenko SV, Palueva AA (2002) Tectonic evolution and volcano-tectonic zoning of Kurile-Kamchatka island-arc system (in Russian). Geotectonic 4:64-80

Ayers JC (1993) Partitioning and mass-balance relation in lherzolites. Chem Geol 107:19-27

Ayers J (1998) Trace element modeling of aqueous fluid - peridotite interaction in the mantle wedge of subduction zones. Contrib Miner Petrol 132:390-404

Baranov BV, Seliverstov NI, Muravev AV, Muzurov EL (1991) The Komandorsky Basin as a product of spreading behind a transform plate boundary. Tectonophysics 199(2-4):237-245

Bazanova LI, Pevzner MM (2001) Khangar-one more active volcano of Kamchatka (in Russian). Dokl Acad Sci 377(6):800-802 
Bedard JH (1994) A procedure for calculating the equilibrium distribution of trace elements among the minerals of cumulate rocks, and the concentration of trace elements in the coexisting liquids. Chem Geol 118:143-153

Brenan JM, Shaw HF, Ryerson FJ, Phinney DL (1995) Mineralaqueous fluid partitioning of trace elements at $900^{\circ} \mathrm{C}$ and 2.0Gpa: Constraints on the trace element chemistry of mantle and deep crustal fluids. Geochim Cosmochim Acta 59(16):33313350

Bychkov KA, Plechov PU, Ariskin AA (2003) Evaluation of crystallizaion conditions of areal basalts of Terpuk area (Sredinny Range, Kamchatka). Vestnik Otdelenia nauk o Zemle RAN $1 / 21: 1-3$, in Russian

Calkins J (2004) ${ }^{40} \mathrm{Ar} /{ }^{39} \mathrm{Ar}$ geochronology of Khapitsa Plateau and Studyonaya River basalts and basaltic andesites in Central Kamchatka Depression, Kamchatka, Russia. Abstr IV JKASP Int workshop

Churikova T, Dorendorf F, Wörner G (2001) Sources and fluids in the mantle wedge below Kamchatka, evidence from across-arc geochemical variation. J Petrol 42(8):1567-1593

Churikova T, Wörner G, Mironov N, Kronz A (2007) Volatile (S, Cl and $\mathrm{F}$ ) and fluid mobile trace element compositions in melt inclusions: Implications for variable fluid sources across the Kamchatka arc. Contrib Miner Petrol 154(2):217-239

Davaille A, Lees JM (2004) Thermal modeling of subducted plates: tear and hotspot at the Kamchatka corner. Earth Planet Sci Lett 226:293-304

DeMets C, Gordon RG, Argus DF, Stein S (1990) Current plate motions. Geophys J Int 101:425-478

Dirksen OV, Bazanova LI, Pletchov PU, Portnyagin MV, Bychkov KA (2004) Volcanic activity at Sedankinsky dol lava field, Sredinny ridge during the Holocene (Kamchatka, Russia). Abstr IV Int JKASP Workshop, pp 55-56

Dorendorf F, Churikova T, Koloskov A, Wörner G (2000a) Late Pleistocene to Holocene activity at Bakening volcano and surrounding monogenetic centers (Kamchatka): volcanic geology and geochemical evolution. J Volcanol Geotherm Res 104:131-151

Dorendorf F, Wiechert U, Wörner G (2000b) Hydrated sub-arc mantle: a source for the Kluchevskoy volcano, Kamchatka/ Russia. Earth Planet Sci Lett 175:69-86

Duggen S, Portnyagin M, Baker J, Ulfbeck D, Hoernle K, GarbeSchonberg D, Grassineau N (2007) Drastic shift in lava geochemistry in the volcanic-front to rear-arc region of the Southern Kamchatkan subduction zone: Evidence for the transition from slab surface dehydration to sediment melting. Geochim Cosmochim Acta 71:452-480

Fedorov PI, Shapiro MN (1998) Neogene volcanics of Kamchatka isthmus and geodynamic of Aleutian-Kamchatka junction. Geotectonics 2:60-76 (in Russian)

Foley S (1991) High-pressure stability of the fluor- and hydroxyendmembers of pargasite and K-richterite. Geochim Cosmochim Acta 55:2689-2694

Foley SF, Jackson SE, Fryer BJ, Greenough JD, Jenner GA (1996) Trace element partition coefficients for clinopyroxene and phlogopite in an alkaline lamprophyre from Newfoundland by LAM-ICP-MS. Geochim Cosmochim Acta 60/4:629-638

Frey FA (1969) Rare earth abundances in a high-temperature peridotite intrusion. Geochim Cosmochim Acta 33(11):14291447

Fumagalli P, Poli S (2005) Experimentally determined phase relations in hydrous peridotites to $6.5 \mathrm{GPa}$ and their consequences on the dynamics of subduction zones. J Petrol 46(3):555-578

Geological map and map of the ore deposits of Kamchatka area and Koryak autonomous area 1:1500000 (In Russian). In: Litvinov AF, Markovsky BA, Zaytsev VP (eds) VSEGEI, 2005
Gill JB (1981) Orogenic andesites and plate tectonics. Springer, Berlin, p 358

Gorbatov A, Kostoglodov V, Suarez G (1997) Seismicity and structure of the Kamchatka subduction zone. J Geophys Res 102(B8): 17883-17898

Gorelchik VI, Garbuzova VG, Droznin DV, Levina VI, Firstov PP, Chubarova OS, Shirokov VA (1996) Shilevuch volcano: deep structure and eruption forecast on a base of detailed seismicity data 1962-1994. Volcanol Seismol 4-5:54-76 in Russian

Green TH, Blundy JD, Adam J, Yaxley GM (2000) SIMS determination of trace element partition coefficients between garnet, clinopyroxene and hydrous basaltic liquids at 2-7.5 GPa and 1080-1200 ${ }^{\circ} \mathrm{C}$. Lithos 53(3):165-187

Gregoire M, Moine BN, O'Reilly SY, Cottin JY, Giret A (2000) Trace element residence and partitioning in mantle xenoliths metasomatised by highly alkaline, silicate- and carbonate-rich melts (Kerguelen Islands, Indian Ocean). J Petrol 41:477-509

Halliday AN, Lee DC, Tommasini S, Davies GR, Paslick CR, Fitton JG, James DE (1995) Incompatible trace elements in OIB and MORB and source enrichment in the sub-oceanic mantle. Earth Planet Sci Lett 133:379-395

Hart SR, Dunn T (1993) Experimental cpx/melt partitioning of 24 trace elements. Contrib Miner Petrol 113(1):1-8

Hartmann G (1994) The late-medieval glass manufacture in the Eichsfeld region (Germany). Chemie der Erde 54:103-128

Hartmann G, Wedepohl KH (1993) The composition of peridotite tectonites from the Ivrea complex (N-Italy) Residues from melt extraction. Geochim Cosmochim Acta 57:1761-1782

Hattori KH, Guillot S (2003) Volcanic front form as a consequence of serpentinite dehydration in the forearc mantle wedge. Geol 31(6):525-528

Hauri EH, Wagner TP, Grove TL (1994) Experimental and natural partitioning of $\mathrm{Th}, \mathrm{U}, \mathrm{Pb}$ and other trace elements between garnet, clinopyroxene and basaltic melts. Chem Geol 117(14):149-166

Hofmann AW (1988) Chemical differentiation of the Earth; the relationship between mantle, continental crust, and oceanic crust. Earth Planet Sci Lett 90(3):297-314

Ionov DA, Griffin WL, O’Reilly SY (1997) Volatile-bearing minerals and lithophile trace elements in the upper mantle. Chem Geol 141(3-4):153-184

Jagoutz E, Palme H, Baddenhausen H, Blum K, Cendales M, Dreibus G, Spettel B, Lorenz V, Waenke H (1979) The abundances of major, minor and trace elements in the Earth's mantle as derived from primitive ultramafic nodules. In: Merrill RB, Bogard DD, Hoerz F, McKay DS, Robertson PC (eds) Proc 10th Lunar Sci Conf, pp 2031-2050

Johnson KTM (1994) Experimental cpx/and garnet/melt partitioning of REE and other trace elements at high pressures; petrogenetic implications. Miner Mag 58:454-455

Johnson KTM (1998) Experimental determination of partition coefficients for rare earth and high-field-strength elements between clinopyroxene, garnet, and basaltic melt at high pressures. Contrib Miner Petrol 133(1-2):60-68

Kelemen PB, Joyce DB, Webster JD, Holloway JR (1990) Reaction between ultramafic rock and fractionating basaltic magma II. Experimental investigation of reaction between olivine tholeiite and harzburgite at $1150-1050^{\circ} \mathrm{C}$ and $5 \mathrm{~kb}$. J Petrol 3(1):99-134

Kelemen PB, Shimizu N, Dunn T (1993) Relative depletion of niobium in some arc magmas and the continental crust: partitioning of $\mathrm{K}, \mathrm{Nb}, \mathrm{La}$ and $\mathrm{Ce}$ during melt/rock reaction in the upper mantle. Earth Planet Sci Lett 120:111-134

Kennedy AK, Lofgren GE, Wasserburg GJ (1993) An experimental study of trace element partitioning between olivine, orthopyroxene and melt in chondrules: equilibrium values and kinetic effects. Earth Planet Sci Lett 115(1-4):177-195 
Keppler H (1996) Constrains from partitioning experiments on the composition of subduction-zone fluids. Nature 380:237-240

Kersting AB, Arculus RJ (1995) Pb isotope composition of Kluchevskoy volcano, Kamchatka and North Pacific sediments: Implications for magma genesis and crustal recycling in the Kamchatkan arc. Earth Planet Sci Lett 136:133-148

Kessel R, Schmidt MW, Ulmer P, Pettke T (2005) Trace element signature of subduction-zone fluid, melts and supercritical liquids at $120-180 \mathrm{~km}$ depth. Nature 437:724-727

Kirby SH, Stein S, Okal EA, Rubie DC (1996) Metastable mantle phase transformations and deep earthquake in subducting oceanic lithosphere. Rev Geophys 34:261-306

Koloskov AV (1999) Ultramafic enclaves and volcanics as selfregulated geological system (in Russian). Nauchny Mir, Moscow

Konstantinovskaja EA (2003) Tectonic of the eastern Asian margins: structural development and geodynamic modeling (In Russian). Nauchny Mir, Moscow 224

Lander AV, Shapiro MN (2007) The origin of the modern Kamchatka subduction zone. In: Eichelberger J, Gordeev E, Kasahara M, Izbekov P, Lees $\mathrm{J}$ (eds) Volcanism and tectonics of the Kamchatka peninsula and adjacent arcs. Geophys Monogr Ser 172:57-64

Lander AV, Bukchin BG, Droznin DV, Kiryushin AV (1994) The tectonic environment and source parameters of the Khailino, Koryakiya earthquake of March 8, 1991: Does a Beringia plate exist? Computational Seismol Geodynamics (English edition of the Geodinamika i prognoz zemletriaseniy. Vychislitel'naya seismologiya) 3:80-96

Lanphere MA, Dalrymple GB (2000) First-principles calibration of ${ }^{38} \mathrm{Ar}$ tracers: implications for the ages of ${ }^{40} \mathrm{Ar} /{ }^{39} \mathrm{Ar}$ fluence monitors. U.S. Geoll Surv Prof Pap 1621

LaTourrette T, Hervig RL, Holloway JR (1995) Trace element partitioning between amphibole, phlogopite and basanite melt. Earth Planet Sci Lett 135:13-30

Layer PW (2000) Argon-40/argon-39 age of the El'gygytgyn impact event, Chukotka, Russia. Meteorit Planet Sci 35:591-599

Layer PW, Hall CM, York D (1987) The derivation of ${ }^{40} \mathrm{Ar} /{ }^{39} \mathrm{Ar}$ age spectra of single grains of hornblende and biotite by laser step heating. Geophys Res Lett 14:757-760

Le Maitre RW (ed) (1989) A classification of the igneous rocks and glossary of terms. Recommendations of the International Union of Geological Sciences on the systematics of igneous rocks. Blackwell Scientific Publications, Oxford, p 193

Legler VA (1977) Cenozoic evolution of Kamchatka accordingly to plate tectonics theory (In Russian). In: Sorokhtin OG, Zonenshain LP (eds) Plate tectonics (energy sources of tectonic processes and plate dynamics). Oceanology Institute AS USSR, Moscow, pp 137-169

McCulloch MT, Gamble AJ (1991) Geochemical and geodynamical constraints on subduction zone magmatism. Earth Planet Sci Lett 102:358-374

McDougall I, Harrison TM (1999) Geochronology and thermochronology by the ${ }^{40} \mathrm{Ar} /{ }^{39} \mathrm{Ar}$ method, 2nd edn. Oxford University Press, New York, p 269

McKenzie D, O’Nions RK (1991) Partial melt distributions from inversion of rare Earth element concentrations. J Petrol 32:10211091

Miller DM, Goldstein SL, Langmuir CH (1994) Cerium/lead and lead isotope ratios in arc magmas and the enrichment of lead in the continents. Nature 368:514-520

Münker C, Wörner G, Yogodzinski G, Churikova T (2004) Behavior of high field strength elements in subduction zones: constraints from Kamchatka-Aleutian arc lavas. Earth Planet Sci Lett 224:275-293

Nielsen RL, Gallahan WE, Newberger F (1992) Experimentally determined mineral-melt partitioning coefficient for Sc, $\mathrm{Y}$ and
REE for olivine, orthopyroxene, pigeonite, magnetite and ilmenite. Contrib Miner Petrol 110:488-499

Niida K, Green DH (1999) Stability and chemical composition of pargasitic amphibole in MORB pyrolite under upper mantle conditions. Contrib Miner Petrol 135:18-40

Nikogosian IK, Sobolev AV (1997) Ion-microprobe analysis of melt Inclusions in olivine: experience in estimating the olivine-melt partition coefficients of trace elements. Geochem Int 35:119-126

Noll PD Jr, Newsom HE, Leeman WP, Ryan JG (1996) The role of hydrothermal fluids in the production of subduction zone magmas: evidence from siderophile and chalcophile trace elements and boron. Geochim Cosmochim Acta 60(4):587-611

Ogorodov NV, Kozhemiaka NN, Vazheevskaya AA, Ogorodova AS (1972) Volcanoes and quaternary volcanism of the Sredinny Ridge of Kamchatka (in Russian). Nauka, Moscow

Ozerov AU (2000) The evolution of high-alumina basalts of the Klyuchevskoy volcano, Kamchatka, Russia, based on microprobe analyses of mineral inclusions. J Volcanol Geotherm Res 95:65-79

Park J, Levin V, Brandon M, Lees J, Peyton V, Gordeev E, Ozerov A (2001) A dangling slab, amplified arc volcanism, mantle flow and seismic anisotropy in the Kamchatka Plate Corner. EOS 82(47):F1156

Pearce JA (1983) Role of the sub-continental lithosphere in magma genesis at active continental margins. In: Hawkesworth CJ, Norry MJ (eds) Continental basalts and mantle xenoliths; papers prepared for a UK Volcanic Studies Group meeting at the University of Leicester. Shiva Publ., Nantwich, pp 230-249

Pearce JA (2005) Mantle preconditioning by melt extraction during flow: theory and petrogenetic implications. J Petrol 46(5):973997

Pearce JA, Parkinson IJ (1993) Trace element models for mantle melting; application to volcanic arc petrogenesis. In: Prichard HM, Alabaster T, Harris NBW, Neary CR (eds) Magmatic processes and plate tectonics. Geol Soc London Spec Publ, pp 373-403

Perepelov AB (2004) Neogene-Quaternary shoshonit-latitic magmatism of Sredinny Ridge of Kamchatka: Tekletunup Volcano (geological evolution, petrography, mineralogy) (in Russian). Volcanol Seismol 3:12-30

Perepelov AB (2005) Neogene-Quaternary shoshonit-latitic magmatism of Sredinny Ridge of Kamchatka: Tekletunup Volcano (geochemistry, petrology, geodynamic position) (in Russian). Volcanol Seismol 4:11-36

Perepelov AB, Puzankov MU, Koloskov AV, Ivanov AV, Flerov GB, Baluev EU, Filosofova TM (2006a) Origin of the alcali-basaltic magmas with convergention of intraplate and island-arc geochemical affinities (Bolshoj Pajalpan volcano, Sredinny Range of Kamchatka). In: Volcanizm and geodynamics, vol 3, pp 578583, in Russian

Perepelov AB, Puzankov MU, Ivanov AV, Filosofova TM (2006b) Bazanites of Mt. Khukhch: first mineralogical-geochemical data on the Neogene K-Na alkaline magmatism in Western Kamchatka. Dokl Earth Sci Geochem 409(5):765-768

Pevzner MM (2004) New data on Holocene monogenetic volcanism of the Northern Kamchatka: ages and space distribution. Abstr IVth Int JKASP Workshop, pp 72-74

Pevzner MM (2006) Holocene volcanism of Northern Kamchatka in time and space aspect. Dokl Earth Sci Geol 409A(6):884-887

Pevzner MM, Volynets AO (2006) Holocene volcanism of Sredinny Range, Kamchatka. In: Gordeev EI (ed) Problems of the explosive volcanism (at 50th anniversary of the catastrophic eruption of Bezimyanny volcano). Materials of the first international symposia, pp 127-134, in Russian

Pevzner MM, Melekestsev IV, Volynets ON, Melkii VA (2000) South Cherpuk and North Cherpuk-the largest Holocene monogenetic 
volcanoes on the Sredinny Range of Kamchatka. Volcanol Seismol 21:667-681

Pevzner MM, Ponomareva VV, Bazanova LI (2002) New data on the Kamchatka back-arc volcanism during the Holocene time. Abstr 3rd JKASP Workshop. Fairbanks, Alaska

Plank T, Langmuir CH (1988) An evaluation of the global variations in the major element chemistry of arc basalts. Earth Planet Sci Lett 90:349-370

Plank T, Langmuir CH (1998) The chemical composition of subducting sediment and its consequences for the crust and mantle. Chem Geol 145:325-394

Pletchov P (2008) Multiplicity of the island-arc magma sources and the dynamic of their interaction. Doctor dissertation thesis, Moscow State University, Moscow, Russia, 43 pp, in Russian

Poli S, Schmidt MW (2002) Petrology of the subducted slabs. Ann Rev Earth Planet Sci Lett 30:207-235

Ponomareva VV, Churikova TG, Melekestsev IV, Braitseva OA, Pevzner MM, Sulerzhitsky LD (2007) Late Pleistocene-Holocene volcanism on the Kamchatka peninsula, Northwest Pacific region. In: Eichelberger J, Gordeev E, Kasahara M, Izbekov P, Lees $\mathbf{J}$ (eds) Volcanism and tectonics of the Kamchatka peninsula and adjacent arcs. Geophys Monograph Series 172, pp $165-198$

Portnyagin M, Hoernle K, Avdeiko G, Hauff F, Werner R, Bindeman I, Uspensky V, Garbe-Schönberg D (2005) Transition from arc to oceanic magmatism at the Kamchatka-Aleutian junction. Geol 33(1):25-28

Portnyagin M, Hoernle K, Plechov P, Mironov M, Khubunaya S (2007a) Constraints on mantle melting and composition and nature of slab components in volcanic arcs from volatiles $\left(\mathrm{H}_{2} \mathrm{O}\right.$, $\mathrm{S}, \mathrm{Cl}, \mathrm{F}$ ) and trace elements in melt inclusions from the Kamchatka Arc. Earth Planet Sci Lett 255(1-2):53-69

Portnyagin M, Bindeman I, Hoernle K, Hauff F (2007b) Geochemistry of primitive lavas of the Central Kamchatka Depression: Magma generation at the edge of the Pacific Plate. In: Eichelberger J, Gordeev E, Kasahara M, Izbekov P, Lees J (eds) Volcanism and tectonics of the Kamchatka peninsula and adjacent arcs. Geophys Monograph Series 172, pp 199-239

Rollinson H (1993) Using geochemical data: evaluation, presentation, interpretation. Longman Scientific \& Technical, New York

Samson SD, Alexander EC (1987) Calibration of the interlaboratory ${ }^{40} \mathrm{Ar} /{ }^{39} \mathrm{Ar}$ dating standard, MMhb1. Chem Geol 66:27-34

Schmidt MW, Poli S (1998) Experimentally based water budgets for dehydrating slabs and consequences for arc magma generation. Earth Planet Sci Lett 163:361-379

Scholl DW (2007) Viewing the tectonic evolution of the KamchatkaAleutian (KAT) connection with an Alaska crustal extrusion perspective. In: Eichelberger J, Gordeev E, Kasahara M, Izbekov $\mathrm{P}$, Lees $\mathbf{J}$ (eds) Volcanism and tectonics of the Kamchatka peninsula and adjacent arcs. Geophys Monograph Series 172, pp $3-35$

Seliverstov NI (1998) Structure of the near-Kamchatka sea bottom and geodynamics of the Kuril-Kamchatka-Aleutian triple junction (in Russian). Nauchnij mir, Moscow

Sobolev AV, Migdisov AA, Portnyagin MV (1996) Incompatible element partitioning between clinopyroxene and basalt liquid revealed by the study of melt inclusions in minerals from Troodos lavas, Cyprus. Petrol 4(3):307-317

Stalder R, Ulmer P, Thompson AD, Gunther D (2001) High pressure fluids in the $\mathrm{MgO}-\mathrm{SiO} 2-\mathrm{H} 2 \mathrm{O}$ under upper mantle conditions. Contrib Miner Petrol 140:607-618

Steiger RH, Jaeger E (1977) Subcommission on geochronology: Convention on the use of decay constants in geo and cosmochronology. Earth Planet Sci Lett 36:359-362

Stolper E, Newman S (1994) The role of water in the petrogenesis of Mariana trough magmas. Earth Planet Sci Lett 121:293-325
Sun SS, McDonough WF (1989) Chemical and isotopic systematics of oceanic basalts; implications for mantle composition and processes. In: Saunders AD, Norry MJ (eds) Magmatism in the ocean basins. Geol Soc London Spec Publ, pp 313-345

Tatsumi Y, Kogiso T, Nohda S (1995) Formation of a third volcanic chain in Kamchatka: generation of unusual subduction-related magmas. Contrib Miner Petrol 120:117-128

Todt W, Cliff RA, Hanser A, Hofmann AW (1984) ${ }^{202} \mathrm{~Pb}-{ }^{205} \mathrm{~Pb}$ spike for $\mathrm{Pb}$ isotope analysis. Terra Cognita 4:209

Trubitsin VP, Shapiro MN, Rikov VV (1998) Numerical modeling of the Pre-Pliocene mantle flow in junction region of the KurilKamchatka and Aleutian island arcs. Phys Earth 4:10-19, in Russian

Tsvetkov AA, Gladkov NG, Volynets ON (1989) Problem of sediments subduction and ${ }^{10} \mathrm{Be}$ isotope in Kurile island and Kamchatka lavas. DAN USSR 306/5:1220-1225, in Russian

Volynets ON (1994) Geochemical types, petrology, and genesis of late Cenozoic volcanic rocks from the Kurile-Kamchatka island arc system. Int Geol Rev 36:373-405

Volynets AO (2006) Pleistocene-Holocene volcanism of Sredinny Range, Kamchatka: rocks composition and geodynamic interpretation. Ph. D. thesis, Moscow State University, $195 \mathrm{pp}$

Volynets AO, Churikova TG (2004) Petrography and geochemistry of products of Ichinsky zone of monogenetic volcanism (Sredinny Ridge of Kamchatka): participation of different sources in magma generation. Abstracts of the XXXVII Tectonic Meeting "Evolution of tectonic processes in Earth history", pp 143-147, in Russian

Volynets ON, Patoka MG, Melekestsev IV, Zubin MI (1991) Ichinsky volcano. In: Fedotov SA, Masurenkov YP (eds) Active volcanoes of Kamchatka, vol 1, pp 282-294

Wallace ME, Green DH (1991) The effect of bulk rock composition on the stability of amphibole in the upper mantle: implications for solidus positions and mantle metasomatism. Miner Petrol 44:1-19

White WM (2000) Geochemistry. An online textbook: http://www. geo.cornell.edu/geology/classes/geo455/Chapters.HTML

Workman RK, Hart SR (2005) Major and trace element composition of the depleted MORB mantle (DMM). Earth Planet Sci Lett 231(1-2):53-72

Wörner G, Churikova T, Leeman W, Liebetrau V, Tonarini S, Heuser A (2001) Fluid-mobile trace element and U-series isotope variations across Kamchatka: timing and effects of slab dehytratation. Margins Meeting, Schriftenreihe D. Geol Ges 14:236237

Yogodzinski GM, Kay RW, Volynets ON, Koloskov AV, Kay SM (1995) Magnesian andesite in the western Aleutian Komandorsky region: implications for slab melting and processes in the mantle wedge. Geol Soc Am Bull 107:505-519

Yogodzinski GM, Lees JM, Churikova TG, Dorendorf F, Wörner G, Volynets ON (2001) Geochemical evidence for the melting of subducting oceanic lithosphere at plate edges. Nature 409:500504

Yokoyama T, Makishima A, Nakamura E (1999) Evaluation of the coprecipitation of incompatible trace elements with fluoride during silicate rock dissolution by acid digestion. Chem Geol 157:175-187

York D, Hall CM, Yanase Y, Hanes JA, Kenyon WJ (1981) ${ }^{40} \mathrm{Ar} /{ }^{39} \mathrm{Ar}$ dating of terrestrial minerals with a continuous laser. Geophys Res Lett 8:1136-1138

Zack T, Foley SF, Jenner GA (1997) A consistent partition coefficient set for clinopyroxene, amphibole and garnet from laser ablation microprobe analysis of garnet pyroxenites from Kakanui, New Zealand. N Jahrb Miner Abh 172:23-41

Zonenshain LP, Savostin LA (1979) Introduction geodynamics, Nedra, Moscow (in Russian) 